\title{
1 An inter-laboratory stability study of roll-to-roll coated flexible polymer solar modules
}

Suren A. Gevorgyan, ${ }^{1}$ Andrew J. Medford, ${ }^{1}$ Eva Bundgaard, ${ }^{1}$ Subarna B. Sapkota, ${ }^{2}$ Hans-Frieder Schleiermacher, ${ }^{2}$ Birger Zimmermann, ${ }^{2}$ Uli Würfel, ${ }^{2}$ Amine Chafiq, ${ }^{3}$ Monica Lira-Cantu, ${ }^{3}$ Thomas Swonke, Michael Wagner, Christoph J. Brabec, ${ }^{4}$ Olivier Haillant, ${ }^{5}$ Eszter Voroshazi, ${ }^{6,7}$ Tom Aernouts, ${ }^{6}$ Roland Steim, ${ }^{8}$ Jens A. Hauch, ${ }^{8}$ Andreas Elschner, ${ }^{9}$ Michael Pannone, ${ }^{10}$ Min Xiao, ${ }^{10}$ Anthony Langzettel, ${ }^{10}$ Darin Laird, ${ }^{10}$ Matthew T. Lloyd, ${ }^{11}$ Thomas Rath, ${ }^{12,13}$ Eugen Maier, ${ }^{13,14}$ Gregor Trimmel, ${ }^{12,13}$ Martin Hermenau, ${ }^{15}$ Torben Menke, ${ }^{15}$ Karl Leo, ${ }^{15}$ Roland Rösch, ${ }^{16}$ Marco Seeland, ${ }^{16}$ Harald Hoppe, ${ }^{16}$ Timothy J. Nagle, ${ }^{17}$ Kerry B. Burke, ${ }^{17}$ Christopher J. Fell, ${ }^{17}$ Doojin Vak, ${ }^{18}$ Th. Birendra Singh, ${ }^{18}$ Scott E. Watkins, ${ }^{18}$ Yulia Galagan, ${ }^{19}$ Assaf Manor, ${ }^{20}$ Eugene A. Katz, ${ }^{20,21}$ Taehee Kim ${ }^{22}$, Kyungkon Kim ${ }^{22}$ Paul M. Sommeling, ${ }^{23}$ Wiljan J. H. Verhees, ${ }^{23}$ Sjoerd C. Veenstra, ${ }^{23}$ Moritz Riede, ${ }^{24,15}$ Greyson M. Christoforo, ${ }^{24}$ Travis Currier, ${ }^{25}$ Vishal Shrotriya, ${ }^{25}$ Gregor Schwartz, ${ }^{26}$ and Frederik C. Krebs ${ }^{1, *}$

\footnotetext{
${ }^{1}$ Ris $\emptyset$ National Laboratory for Sustainable Energy, Technical University of Denmark, Frederiksborgvej 399, DK-4000 Roskilde, Denmark

${ }^{2}$ Fraunhofer Institute for Solar Energy Systems ISE, Heidenhofstrasse 2, D-79110 Freiburg, Germany

${ }^{3}$ Centre d'investigació en Nanociència I Nanotecnologia (CIN2, CSIC). Laboratory of Nanostructured Materials for Photovoltaic Energy. ETSE, Campus UAB, Edifici Q, 2nd Floor. E-08193. Bellaterra (Barcelona), Spain

${ }^{4}$ Bavarian Center for Applied Energy Research, Am Weichselgarten 7, D-91058 Erlangen, Germany

${ }_{5}^{5}$ Atlas Material Testing Technology, Vogelsberstrasse 22, 63859 Linsengericht - Altenhasslau

${ }^{6}$ IMEC VZW. - Organic Photovoltaics, Kapeldreef 75, B-3001 Leuven, Belgium

${ }^{7}$ Katholieke Universiteit Leuven, ESAT, Kasteelpark Arenberg 10, B-3001 Leuven, Belgium

${ }^{8}$ Konarka Technologies GmbH, Landgrabenstr. 94, 90443 Nürnberg, Germany

${ }^{9}$ H.C. Starck Clevios GmbH, Chempark Leverkusen Build. B202, D-51368 Leverkusen, Germany

${ }^{10}$ Plextronics, Inc., 2180 William Pitt Way, Pittsburgh, PA 15238, USA

${ }^{11}$ National Renewable Energy Laboratory, Golden, Colorado, 80401, USA

${ }^{12}$ Christian Doppler Laboratory for Nanocomposite Solar Cells, Graz University of Technology, Stremayrgasse 9, 8010 Graz, Austria

${ }^{13}$ Institute for Chemistry and Technology of Materials, Graz University of Technology, Stremayrgasse 9, 8010 Graz, Austria

${ }^{14}$ Polymer Competence Center Leoben GmbH, Roseggerstrasse 12, 8700 Leoben, Austria

${ }^{15}$ Institut fuer Angewandte Photophysik, Technische Universitaet Dresden, George-Baehr-Straße 1, 01062 Dresden, Germany

${ }^{16}$ Institute of Physics, Ilmenau University of Technology, Weimarer Str. 32, D-98693 Ilmenau, Germany

${ }^{17}$ CSIRO Future Manufacturing Flagship and CSIRO Energy Technology, 10 Murray Dwyer Circuit, Mayfield West, NSW, 2304, Australia

${ }^{18}$ CSIRO Future Manufacturing Flagship and CSIRO Materials Science and Engineering, Ian Wark Laboratory, Clayton, VIC, 3168 , Australia

${ }^{19}$ Holst Centre, PO Box 8550, $5605 \mathrm{KN}$ Eindhoven, the Netherlands

${ }^{20}$ Dept. of Solar Energy and Environmental Physics, J. Blaustein Institutes for Desert Research, Ben-Gurion University of the Negev, Sede Boker Campus 84990, Israel

${ }^{21}$ The Ilse Katz Institute for Nanoscale Science and Technology, Ben-Gurion University of the Negev, Beersheva 84105, Israel
} 


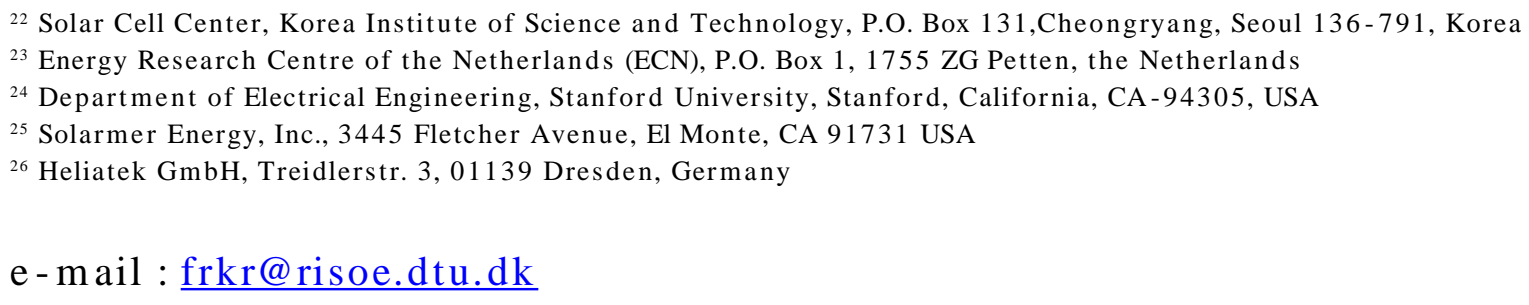

\section{Abstract}

A large number of flexible polymer solar modules comprising 16 serially connected individual cells were prepared at the experimental workshop at Risø DTU. The photoactive layer was prepared from several varieties of P3HT (Merck, Plextronics, BASF and Rieke) and two varieties of $\mathrm{ZnO}$ (nanoparticulate, thin film) were employed as electron transport layers. The devices were all tested at Ris $\varnothing$ DTU and the functional devices were subjected to an inter-laboratory study involving the performance and the stability of the modules over time in the dark, under light soaking and outdoor conditions. 24 laboratories from 10 countries and across 4 different continents were involved in the studies. The reported results allowed analyzing the variability of different groups in performing lifetime studies as well as performing a comparison of different testing procedures. These studies constitute the first steps towards establishing standard procedures for OPV lifetime characterization.

Keywords: round robin, inter laboratory study, polymer solar cells, flexible modules, outdoor testing, R2R manufactured $O P V$. 


\subsection{Introduction}

Round robins (RR) and inter-laboratory studies (ILS) are useful methods to reach a consensus on solar cell performance. This has been employed recently for polymer solar cells [1] and in the past for inorganic solar cells [2-9]. Furthermore, RR and ILS can help in establishing standard procedures for accurate quantification of device performance. In the case of polymer solar cells that present a dynamic response and often pronounced degradative behavior [10] it is of importance to evaluate the stability of these devices and gain consensus on what stability means, how it is observed and how it is quantified. The organic photovoltaics (OPV) community does make use of calibration laboratories, such as NREL (US) and Fraunhofer ISE (Germany), for standardized efficiency measurements but there is an urgent need for internationally accepted ageing and test procedures and it is desirable to develop and maintain some standard procedures for measuring and reporting the stability of OPV devices. Furthermore, flexible roll-to-roll (R2R) processed solar cells represent the most feasible scale-up route for the polymer solar technology and it is thus of interest to investigate the stability of such devices under a variety of conditions and outdoor climates. The two International Summits on Organic Photovoltaic Stability (ISOS-1 and ISOS-2) have attempted on establishing standard protocols for lifetime tests [11] and ISOS-3 is underway. An inter-laboratory stability study provides a powerful route to simultaneously gain insight into the variance between stability measurements under a set of conditions in various laboratories and can explore the effect of a wide range of testing conditions and materials. 
In this report we detail the results of such an inter-laboratory study of flexible R2R processed polymer solar cells with various layer structures that were prepared in one location and distributed to a multitude of laboratories where shelf life and light soak stability tests were carried out under pre-determined conditions. In addition, outdoor exposure testing was also included to provide additional insight into the realistic stability of the cells. Based on the data that were collected we evaluate the current status of standardization between different laboratories involved with polymer solar cell research and correlate data from testing under simulated and stability testing and stability in actual outdoor conditions.

\subsection{Experimental procedure and methodology}

\subsubsection{Manufacture of polymer solar cells}

The manufactured devices had the following structure: PET/ITO/Electron Transporting Layer (ETL)/Active Layer/PEDOT:PSS/Ag paste. The types of ETL as well as the types of polymers used in a bulk mixture with PCBM for active layers are presented in Table 1. Four different device variations were produced, as listed in Table 1.

Table 1. Active polymer and electron transport layer for various module types.

\begin{tabular}{|l|l|l|}
\hline Module Type & Active Material & Electron Transport Layer \\
\hline RN & Risø DTU P3HT & Nanoparticulate ZnO \\
\hline ST & Sepiolid P3HT & Thin film ZnO \\
\hline PN & Plextronics P3HT & Nanoparticulate ZnO \\
\hline MN & Merck P3HT & Nanoparticulate ZnO \\
\hline
\end{tabular}


PET/ITO: The flexible substrate comprised ITO covered poly(ethylene terephthalate) (PET) $(130 \mu \mathrm{m})$ in rolls having a roll width of $305 \mathrm{~mm}$ and a length of $100 \mathrm{~m}$. The nominal sheet resistance was $60 \Omega$ square $^{-1}$. The desired striped pattern of the ITO was prepared by printing a UV-curable etch resist in the areas of the ITO pattern in a full $R 2 R$ process. The ITO was subsequently etched using a full R2R etching machine comprising etching baths $\left(\mathrm{CuCl}_{2}\right)$, stripping baths $(\mathrm{NaOH})$, washing baths (demineralised water) and drying sections (hot air). The thickness of the ITO was 80 $\mathrm{nm}$. The process has been described earlier [12].

$\mathrm{ZnO}$ : Zinc oxide nanoparticles ( $\mathrm{ZnO} \mathrm{np}$ ) were prepared in acetone solution and stabilized with methoxyethoxyacetic acid (MEA). The preparation of thin film ZnO was included in this effort as it present devices without an inflection point in the IVcurve [14]. The $\mathrm{ZnO}$ layer was applied using a modified slot-die coating procedure [13]. The films were coated with a wet layer thickness of $\sim 5$ micron at a speed of $2 \mathrm{~m}$ min-1. The drying temperature was $140{ }^{\circ} \mathrm{C}(\sim 30$ second drying time).

Active Layer: Four polymers presented in the table 1 were employed: Sepiolid P200 P3HT purchased from BASF; Plextronics P3HT provided by Plextronics; Merck P3HT provided by Merck. The Ris $\varnothing$ DTU P3HT was home made. Polymers were dissolved in chlorobenzene followed by addition of PCBM. A final concentration of $22 \mathrm{mg} \mathrm{mL}^{-1}$ P3HT and $20 \mathrm{mg} \mathrm{mL}^{-1}$ PCBM was employed. The films were coated with a wet layer thickness of $\sim 8$ micron at a speed of $2 \mathrm{~m}$ min-1. The drying temperature was $140{ }^{\circ} \mathrm{C}$ ( 30 second drying time). 
PEDOT:PSS: PEDOT:PSS was purchased as a screen printing paste from Agfa (Orgacon EL-P 5010). It was diluted with isopropanol (1000 g PEDOT:PSS was mixed with $500 \mathrm{~g}$ isopropanol) and shaken vigorously for $1 \mathrm{~h}$. The viscosity was around $200 \mathrm{mPa}$ s. Wetting of the surface of the active layer prior to PEDOT:PSS coating improves the wetting and coating. PEDOT:PSS was dried at temperatures up to $140{ }^{\circ} \mathrm{C}$ with a residence time in the oven of around $5 \mathrm{~min}$.

Printed silver electrode: The silver electrode was a UV-curing type [15] that was screen printed on a flat bed screen printer with a 120 mesh screen having the desired pattern that with a small outline and 16 serially connected cells described earlier [16].

Encapsulation, contacting and cutting of the modules: The encapsulation was achieved by cold lamination of a barrier foil carrying an adhesive on both sides of the completed solar cell. The barrier on the back side was made such that a part of the printed silver electrode was exposed. This served two purposes. Firstly, it enables reliable contacting and secondly it will allow for the cells to exhibit some degradation over the course of this experiment. The modules were cut manually into individual devices and button contacts were applied using an automated machine. All steps and machinery has been detailed earlier [15].

Module Geometry: The geometric sizes of each module were $12 \mathrm{~cm}$ x $8,5 \mathrm{~cm}$. The active area was comprised of 16 serially connected stripes with total area of $35.5 \mathrm{~cm}^{2}$ to be illuminated. Figure 1 shows the sketch of the module. 


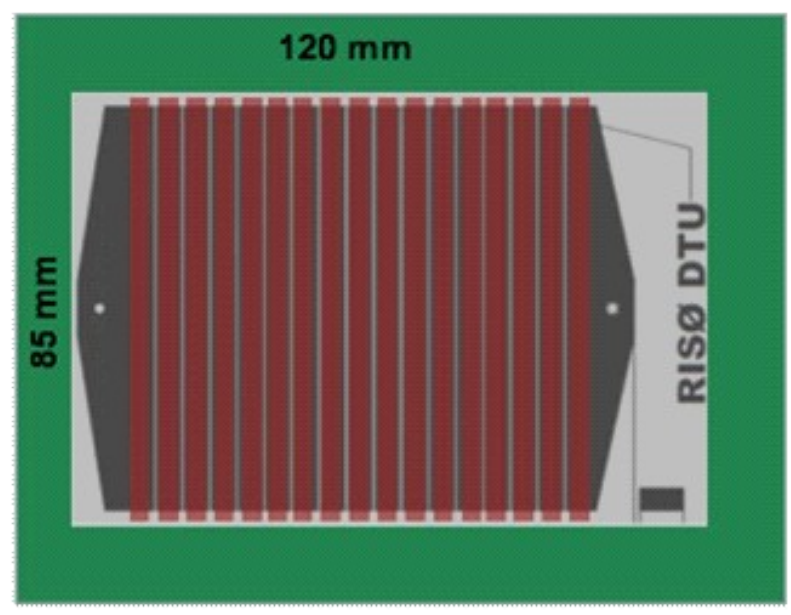

Figure 1. The sketch of the module front side. The dimensions of the module are shown as well.

\subsubsection{Inflection point}

It has been previously observed that $R 2 R$ cells produced using the nanoparticulate $\mathrm{ZnO}$ ink exhibit significant stability issues due to an "inflection point" in the I-V curve, which is developed after dark storage (s-shaped curves). The inflection is sometimes observed immediately after production, and sometimes appears only after several days/weeks of dark storage [14]. It was discovered that this inflection point can be removed via a photo-annealing process in which the cells are left under illumination for 15-60 minutes. Although this phenomenon is not entirely understood, the role of $\mathrm{ZnO}$ photoconductivity is known to be critical, and thus by using light sources with higher UV $(<390 \mathrm{~nm})$ contents the photo-annealing occurs faster. Figure 2 a shows the recovery of IV curves during the photo-annealing of the cell and Figure $2 \mathrm{~b}$ shows the photovoltaic parameters' dynamic behavior along the 
time during the photo-annealing. The inflection point was studied in detail and reported by Lilliedal et al. [14].

The groups that would undertake the further degradation studies of the cells were advised to photo-anneal the modules after receiving them in order to restore their optimal performance. The dynamics of the recovery is highly sensitive to the UV content below $390 \mathrm{~nm}$, and thus if the illumination source is filtered in this range the observations may vary significantly. Thus, the modules performance can vary noticeably based on the UV content of the light used. The groups were also advised to record and report the spectral distributions of their light sources. 

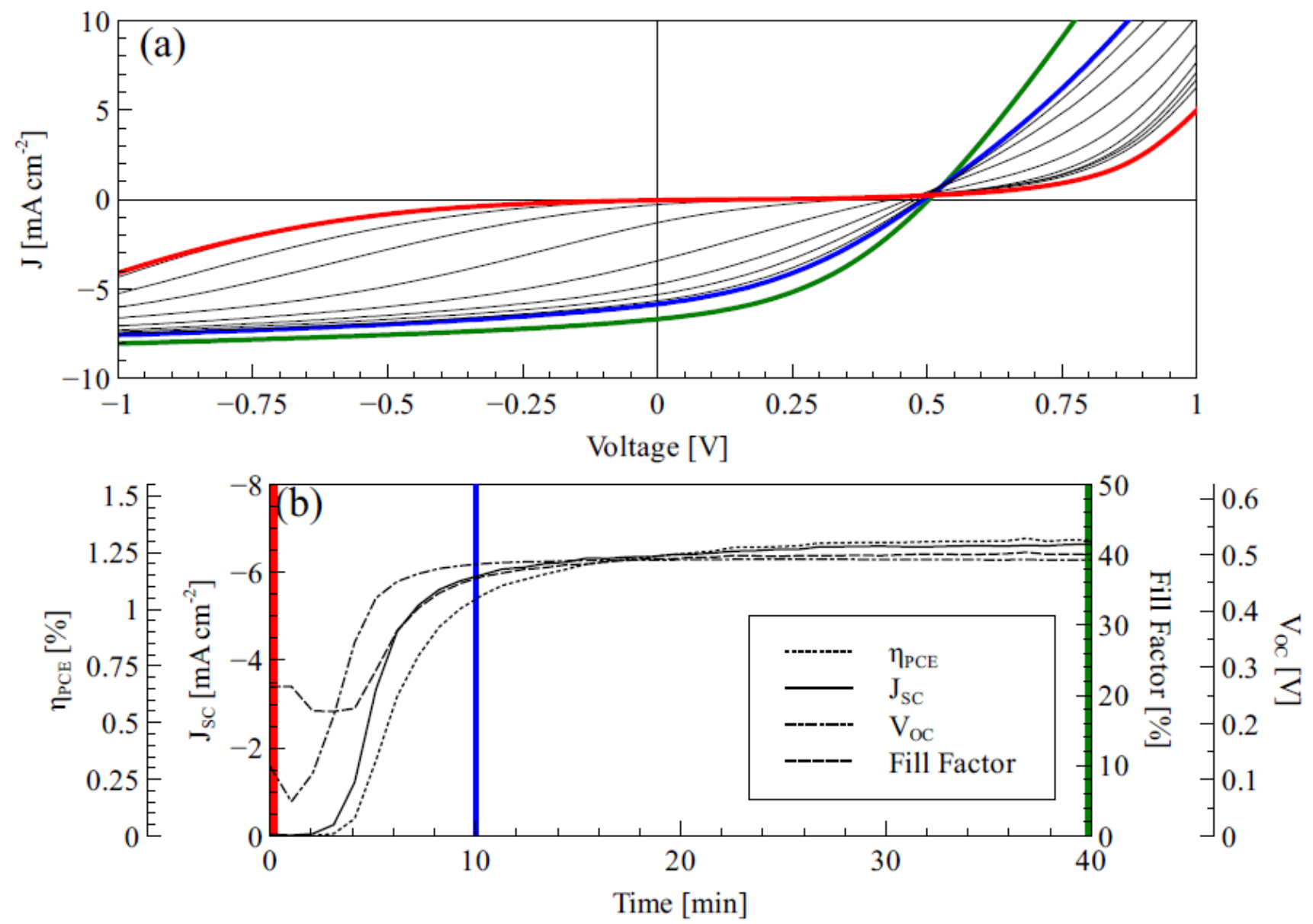

Figure 2. (a) Evolution of IV-curves during photo-annealing of the device at $1000 \mathrm{~W}$ $\mathrm{m}^{-2}, 85 \pm 5{ }^{\circ} \mathrm{C}$. Red is taken at $\mathrm{t}_{0}$, blue after $10 \mathrm{~min}$., green after $40 \mathrm{~min}$. Dynamics of pv parameters during photo-annealing. Colors in (a) correspond to times marked in (b) (reprinted with permission from Elsevier).

\subsubsection{Module selection and package distribution among groups}

The performance of all modules was first recorded using a $R 2 R$ measurement setup [15]. The setup is known to deviate slightly from measurements outdoors due to spectral mismatch and inaccuracies in calibration of intensity, and considerable time 
passed between $R 2 R$ characterization and further calibrated measurements. However, the setup allows for rapid characterization of a large number of cells, and its results are still comparatively useful. The data was used to select functional modules, and estimate that all modules should be in a certain power conversion efficiency range of $\pm 0.3 \%$.

Ideally the performance of all modules would have been recorded under carefully calibrated conditions; however, the amount of time needed to do this was deemed impractical for such a large study, and thus only one cell per package (to be sent to each of the participating laboratories) was carefully measured under both indoor and outdoor test conditions. Secure contacts were attached by placing a button contact on the electrodes of each device. Previous studies at Ris $\varnothing$ DTU have shown that this is usually sufficient to ensure contact throughout the lifetime of the cell. A total of 340 modules were distributed to a total of 24 groups. The modules were prepackaged into 9 samples for standard and 18 samples for extended packages, placed in bubble wrap envelopes and shipped to the groups using ordinary UPS mail service. The packages also included the necessary instructions for testing procedures and a laser cut black cardboard mask for masking the calibrated module prior to measurement. The samples were shipped on the $19^{\text {th }}$ of May 2010 and received on the $24^{\text {th }}$ of May 2010. An email with a description of the ILS stability studies and a request of participation was sent to the list of participants of the ISOS-3 conference. The laboratories that confirmed the participation in the studies received a package 
of modules for testing. The starting date of the experiments was set to the $28^{\text {th }}$ of May 2010 and the studies were scheduled to be completed on the $15^{\text {th }}$ of July 2010.

\subsubsection{Test procedures}

Several standardized testing procedures developed based on the proceedings of ISOS-1/ISOS-2 were distributed along with the cells [17]. It was also suggested that the participating laboratories performed and reported any additional tests which they considered interesting. The standards were simplified in some cases in order to meet the capabilities of a wider range of OPV research groups. The short summary of different procedures of testing is summarized in the table 2 in this paragraph, while more detailed discussions follow in the further sections. Three basic types of measurements were chosen, which involve shelf life studies T1, light soaking in indoor conditions T2 and outdoor studies under real sun T3. T1 and T3 were additionally split to A and B categories making it total of five testing procedures.

Table 2. Short Summary of five stability testing procedures.

\begin{tabular}{|l|l|l|l|l|l|}
\hline Test ID & T1 & T1 & T2 & T3 & T3 \\
\hline Description & Shelf Life A & Shelf Life B & Light Soak & Outdoor A & Outdoor B \\
\hline Light & None & None & 0,6 to 1 sun & $\begin{array}{l}\text { Stored ambient, } \\
\text { measured } \\
\text { Outdoor }\end{array}$ & $\begin{array}{l}\text { Stored ambient, } \\
\text { measured } \\
\text { Indoor }\end{array}$ \\
\hline Temperature & Ambient & $\begin{array}{l}\text { Controlled, 30 } \\
-50{ }^{\circ} \mathrm{C}\end{array}$ & $\begin{array}{l}\text { Controlled, } \\
30-50{ }^{\circ} \mathrm{C}\end{array}$ & Ambient & Ambient \\
\hline Humidity & Ambient & Controlled) & (Controlled) & Ambient & Ambient \\
\hline Environment & Drawer & $\begin{array}{l}\text { Chamber/Dry } \\
\text { Oven }\end{array}$ & $\begin{array}{l}\text { Light } \\
\text { soaking } \\
\text { chamber })\end{array}$ & Ambient & Ambient \\
\hline $\begin{array}{l}\text { Logging } \\
\text { Interval }\end{array}$ & $\begin{array}{l}1 \text { day to } 1 \\
\text { week }\end{array}$ & $\begin{array}{l}1 \text { day to } 1 \\
\text { week }\end{array}$ & $\begin{array}{l}1 \text { min }-15 \\
\text { min }\end{array}$ & 15 min - 1 day & 1 day to 1 week \\
\hline Load & None & None & None & None & None \\
\hline
\end{tabular}




\subsubsection{Calibrated Module Testing}

As previously mentioned each package contained one module, which was carefully measured under both indoor and outdoor conditions at Ris $\varnothing$ DTU prior to shipping. Only the ST type modules (see table 1) were chosen for calibration studies. The cells were masked using laser-cut mask with an aperture of $7.4 \times 7.9 \mathrm{~cm}^{2}$ in order to limit illumination to the active area. The nominal active area of the cells was $35.5 \mathrm{~cm}^{2}$. Cells were tested under indoor conditions using a KHS solar constant 575 solar simulator which was calibrated to an intensity of $1000 \mathrm{~W} \mathrm{~m}^{-2}$ using a pyranometer mounted on the test platform. The temperature was monitored during testing using a thermocouple. No active cooling was used. A photograph of the test setup is shown in Figure 3. Cells were placed under the sun for approximately 5 minutes while the temperature stabilized. The device temperature varied between $\sim 80 \pm 5{ }^{\circ} \mathrm{C}$ and was recorded at the beginning of each scan. Scans were taken from - 1 to $10 \mathrm{~V}$ at a sweep rate of $100 \mathrm{mV} / \mathrm{s}$ and a step speed of $100 \mathrm{~ms}$ (scan time of $11 \mathrm{~s}$ ), and repeated 5 times to ensure that the performance was stable. After the final scan the cell was covered and a dark scan was taken. 


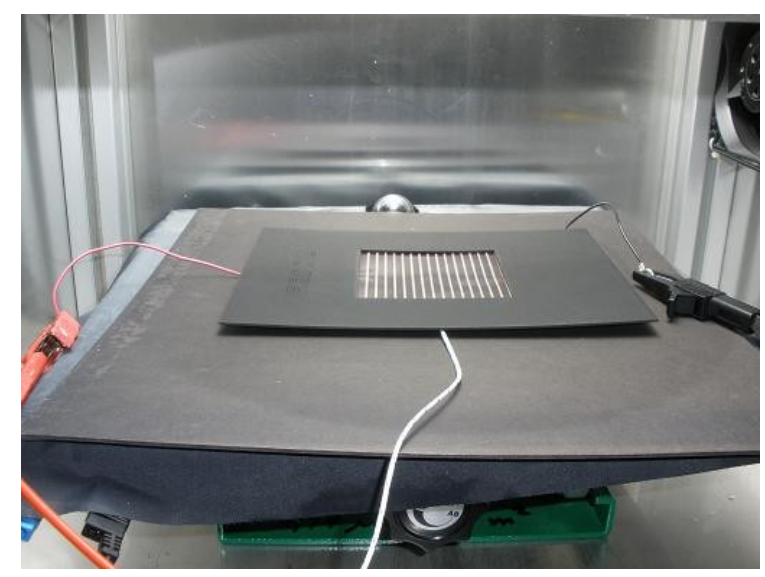

Figure 3. Measurement setup used for indoor testing including pyranometer (dome in back) and thermocouple (white wire).

The 5 files were compiled and summarized to include standard error for each parameter, temperature, and current. Outdoor testing was conducted by mounting the masked cells on a black piece of cardboard backing which was placed on a solar tracker. The intensity of solar illumination was measured using a bolometer attached to the solar tracker, and temperature was monitored by attaching a thermocouple to the back of a reference cell. The temperature varied between $22-28{ }^{\circ} \mathrm{C}$ depending on wind speed, orientation and illumination. IV scans were recorded under the same conditions as during indoor testing, but were only repeated once due to lack of constant solar flux. The measurements were taken on a cloudy day, and thus the intensity is at times slightly over $960 \mathrm{~W} \mathrm{~m}^{-2} \mathrm{due}$ to reflections from clouds in the upper half space viewed by the solar cell. This also contributed to some uncertainty in the solar flux, as it often changed to some extent $\left( \pm 20 \mathrm{~W} \mathrm{~m}^{-2}\right) \mathrm{during}$ measurements. The characterizations of the modules under both indoor and outdoor conditions were performed from 12 to 17 of May 2010 and the packages were 
shipped to the recipient labs on the $19^{\text {th }}$ of May 2010 . The groups were instructed to measure the calibrated modules with a mask under a calibrated light source prior to degradation studies and report the photovoltaic parameters.

\subsubsection{Shelf-life Testing Procedures T1A\&B}

Shelf-life tests were performed by leaving the modules in the dark in either ambient conditions (T1A) or in controlled temperature/humidity chambers (T1B). The procedures recommended to the groups for T1 A\&B are presented in table 3 .

Table 3. Testing protocol for T1A and T1B shelf life studies.

- Store in dark, ambient conditions between testing (drawer will suffice)*

- Temperature of storage ambient

- RH of storage ambient

- Devices Open circuited

- PV Characterization under AM1.5 Solar simulator with 1 sun intensity

- Place the solar cell under the simulator for 1 min with open circuit prior to measurements.

- Record the temperature during the measurement

- Record the I-V curves from $-2 \mathrm{~V}$ to $+10 \mathrm{~V}$ in steps of $100 \mathrm{mV}$ at a speed of $10 \mathrm{~ms}$ per step if possible (The I-V curve measurement could be repeated to establish if the readings are consistent)

- Measuring interval 1 time/day for first 5 days, and every $100 \mathrm{hr}$ or weekly thereafter

- While measuring make sure that devices are illuminated uniformly or report any non-uniform illumination

- (Measuring IPCE)
T1B

- Store in dark, in chamber with controlled conditions between testing. Conditions defined by the experimenter

- Recommended Temperatures of storage 40 - $50{ }^{\circ} \mathrm{C}$ (approximate cell temp during illumination)

- Controlled RH of storage within 30-60\%

- Device open circuited

- PV Characterization under AM1.5 Solar simulator with 1 sun intensity

- Record the I-V curves from $-2 \mathrm{~V}$ to $+10 \mathrm{~V}$ in steps of $100 \mathrm{mV}$ at a speed of $10 \mathrm{~ms}$ per step if possible (The I-V curve measurement could be repeated to establish if the readings are consistent)

- Measuring interval 1 time/day for first 5 days, and every $100 \mathrm{hr}$ or weekly thereafter. Adapt to specific experiments if necessary.

- While measuring make sure that devices are illuminated uniformly or report any non-uniform illumination

- (Measuring IPCE) 
* Ambient conditions are assumed to be indoor conditions $\left(20-25{ }^{\circ} \mathrm{C}, 30-40 \% \mathrm{RH}\right)$

\subsubsection{Light soak Testing Procedures}

Light soaking was performed by placing the modules under simulated sunlight under indoor conditions. The modules were either stored under the illuminated conditions and measured continuously or were taken out and measured under calibrated sun simulators. The procedures recommended to the groups for carrying out T2 studies are presented in table 4.

Table 4. Testing protocol for T2 light soaking studies.

$\mathrm{T} 2$

- Store under illumination at an intensity close to that of 1 sun.

- Temperature range $40-50{ }^{\circ} \mathrm{C}$

- RH within $30-60 \%$

- Device open circuited while not measured

- Record the I-V curves from $-2 \mathrm{~V}$ to $+10 \mathrm{~V}$ in steps of $100 \mathrm{mV}$ at a speed of $10 \mathrm{~ms}$ per step if possible (The I-V curve measurement could be repeated to establish if the readings are consistent)

- Measuring interval $1 \mathrm{~min}$ to $15 \mathrm{~min}$ or the shortest interval possible

- While measuring make sure that the device is illuminated uniformly or report any nonuniform illumination

- $\quad$ Measuring IPCE)

\subsubsection{Outdoor Testing Procedures (T3A\&B)}

Outdoor exposure testing was conducted by storing the modules outdoor. Ideally this could be done by placing the modules on a solar tracker such that they received a maximum solar irradiance; however, simple mounting of the modules on a 
rooftops or stand still platforms tilted approximately to the latitude could also suffice. The modules were tested either by directly using the outdoor illumination along with an outdoor contacting setup (T1A), or by bringing the cells indoors (daily or weekly) and testing them under calibrated light source (T1B). The geographic location is considered to be of importance for these measurements as it will determine the general climate. The following protocols were suggested to the groups for the test:

Table 5. Testing protocols for T3A and T3B outdoor studies

\begin{tabular}{|c|c|}
\hline T1A & T1B \\
\hline $\begin{array}{l}\text { - Store devices outdoors at all times } \\
\text { - } \text { Temperature range ambient } \\
\text { - } \text { Device open circuited while not measured } \\
\text { - PV characterization in outdoors under } \\
\text { good illumination. Illumination intensity } \\
\text { has to be measured while the cells are } \\
\text { characterized } \\
\text { Record the I-V curves from }-2 \mathrm{~V} \text { to }+10 \mathrm{~V} \\
\text { in steps of } 100 \mathrm{mV} \text { at a speed of } 10 \mathrm{~ms} \\
\text { per step if possible (The I-V curve } \\
\text { measurement could be repeated to } \\
\text { establish if the readings are consistent) } \\
\text { Measuring interval } 15 \text { min to } 1 \text { day or the } \\
\text { shortest interval possible } \\
\text { While measuring make sure that the } \\
\text { device is illuminated uniformly or report } \\
\text { any nonuniform illumination } \\
\text { (Measuring IPCE) }\end{array}$ & $\begin{array}{l}\text { - Store devices outdoors at all times not } \\
\text { measured } \\
\text { - Temperature range ambient } \\
\text { - RH range ambient } \\
\text { - Device open circuited while not measured } \\
\text { - PV Characterization under AM1.5 Solar } \\
\text { simulator with } 1 \text { sun intensity } \\
\text { - Record the I-V curves from - } 2 \text { V to }+10 \mathrm{~V} \\
\text { in steps of } 100 \mathrm{mV} \text { at a speed of } 10 \mathrm{~ms} \\
\text { per step if possible (The I-V curve } \\
\text { measurement could be repeated to } \\
\text { establish if the readings are consistent) } \\
\text { Measuring interval } 1 \text { time/day for first } 5 \\
\text { days, and every } 100 \text { hr or weekly } \\
\text { thereafter. Shorter intervals are preferable } \\
\text { - While measuring make sure that the } \\
\text { device is illuminated uniformly or report } \\
\text { any nonuniform illumination } \\
\text { (Measuring IPCE) }\end{array}$ \\
\hline
\end{tabular}




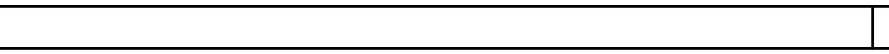

\subsection{Results and Discussion}

\subsubsection{Participating Laboratories}

The study comprised of five types of stability tests plus an accurate quantification of the performance of the calibrated module and the groups had to choose which and how many of the experiments they wished to perform. As mentioned earlier, the modules were shipped to a total of 24 laboratories. 2 laboratories out of 24 performed different kinds of experiments not discussed here. Table 6 shows the list of 22 groups together with the geographic locations of the laboratories and the types of experiments performed. The reported data were analyzed according to the category of the experiment and presented in the next sections.

Table 6. The list of the participating laboratories with the map showing their locations. 


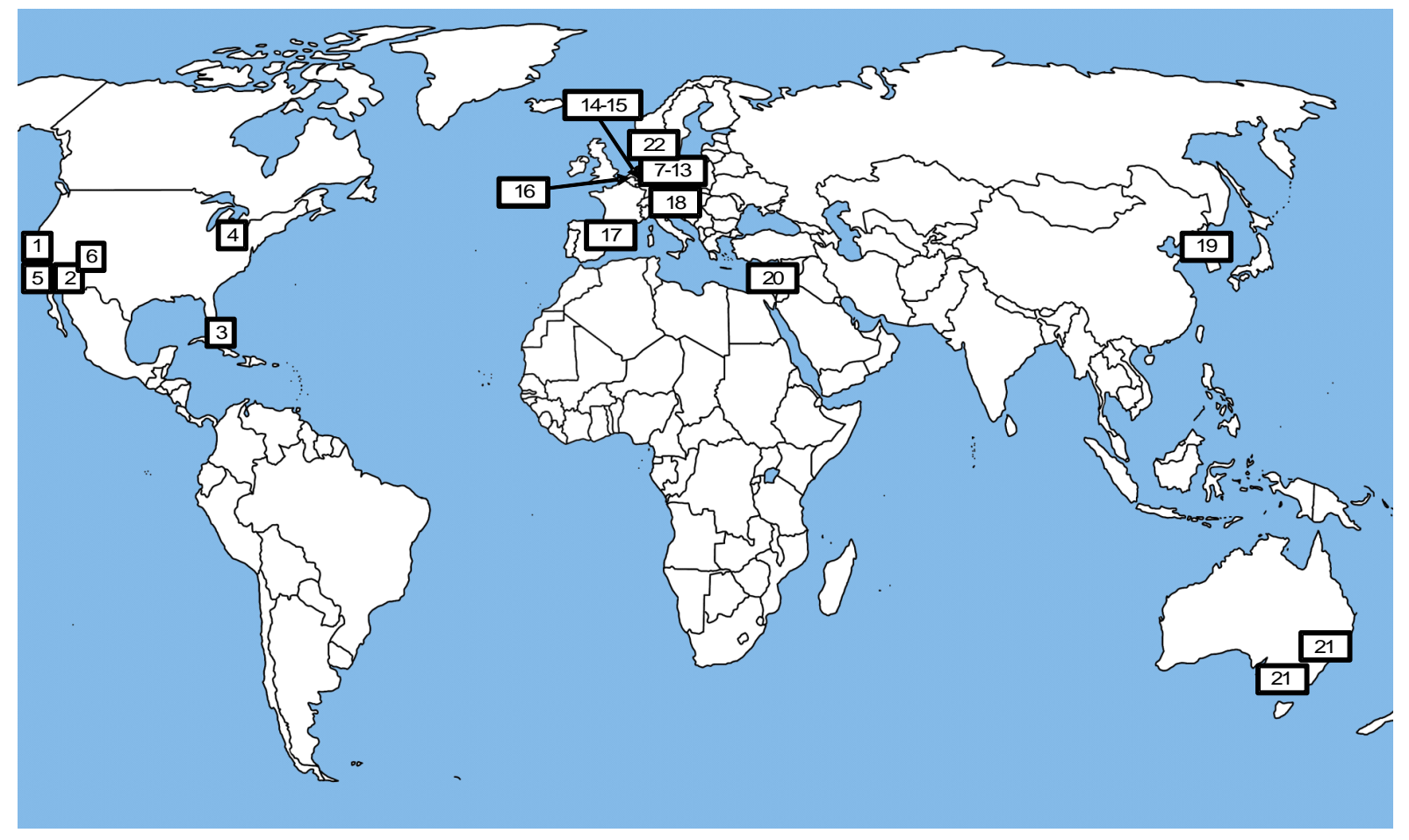

\begin{tabular}{|c|c|c|c|c|}
\hline $\begin{array}{l}\text { Numbe } \\
\mathrm{r}\end{array}$ & Contact Person & Laboratory Name (Country) & Latitude, Longitude & Types of Tests \\
\hline 1 & Riede, M. & Stanford University (USA) & $37^{\circ} 25^{\prime} \quad \mathrm{N}, \quad 122^{\circ} 10^{\prime}$ & $\mathrm{T} 3 \mathrm{~A}$ \\
\hline 2 & Wonders, & Atlas Weathering Services & $33^{\circ} 53^{\prime} \mathrm{N}, 112^{\circ} 9^{\prime} \mathrm{W}$ & T3B* \\
\hline 3 & Rivera, & Atlas South Florida Test & $25^{\circ} 33^{\prime} \mathrm{N}, 80^{\circ} 27^{\prime} \mathrm{W}$ & T3B* \\
\hline 4 & Xiao, M. & Plextronics Inc., (USA) & $40^{\circ} 32^{\prime} \mathrm{N}, 79^{\circ} 49^{\prime} \mathrm{W}$ & $\mathrm{T} 1 \mathrm{~A}, \mathrm{~T} 1 \mathrm{~B}, \mathrm{~T} 2$ \\
\hline 5 & Shrotriya, V. & Solarmer (USA) & $34^{\circ} 4^{\prime} \mathrm{N}, 118^{\circ} 3^{\prime} \mathrm{W}$ & T1A, T1B, T3B \\
\hline 6 & Lloyd, M. & NREL (USA) & $39^{\circ} 44^{\prime} \mathrm{N}, 105^{\circ} 10^{\prime}$ & T1A, T1B, T2 \\
\hline 7 & Hauch, J. & Konarka (Germany) & $49^{\circ} 26^{\prime} \mathrm{N}, 11^{\circ} 4^{\prime} \mathrm{E}$ & T1A, T1B, T2 \\
\hline 8 & Hermenau, M. & IAPP (Germany) & $51^{\circ} 1^{\prime} \mathrm{N}, 13^{\circ} 43^{\prime} \mathrm{E}$ & $\mathrm{T} 1 \mathrm{~A}, \mathrm{~T} 1 \mathrm{~B}, \mathrm{~T} 2$ \\
\hline 9 & Schwartz, G. & Heliatek GmbH (Germany) & $51^{\circ} 4^{\prime} \mathrm{N}, 13^{\circ} 41^{\prime} \mathrm{E}$ & T1A, $\quad$ T1B, $\quad$ T2, \\
\hline 10 & Hoppe, H. & TU Ilmenau (Germany) & $50^{\circ} 41^{\prime} \mathrm{N}, 10^{\circ} 55^{\prime} \mathrm{E}$ & $\begin{array}{lll}\text { T1A, } & \text { T2, } & \text { T3A, }\end{array}$ \\
\hline 11 & Elschner, A. & H.C. Starck (Germany) & $51^{\circ} 4^{\prime} \mathrm{N}, 7^{\circ} 0^{\prime} \mathrm{E}$ & T1A, $\quad$ T2, $\quad$ T3A, \\
\hline 12 & Swonke, & ZAE Bayern (Germany) & $49^{\circ} 32^{\prime} \mathrm{N}, 11^{\circ} 1^{\prime} \mathrm{E}$ & T1A, T1B, T3B \\
\hline 13 & Zimmermann, B. & Fraunhofer ISE (Germany) & $48^{\circ} 0^{\prime} \mathrm{N}, 7^{\circ} 50^{\prime} \mathrm{E}$ & T1A, T2, T3B \\
\hline 14 & Veenstra, S.C. & ECN Solar Energy (Holland) & $52^{\circ} 46^{\prime} \mathrm{N}, 4^{\circ} 4^{\prime} \mathrm{E}$ & $\mathrm{T} 1 \mathrm{~A}, \quad \mathrm{~T} 1 \mathrm{~B}, \mathrm{~T} 2$, \\
\hline 15 & Galagan, Y.O. & Holst Center (Holland) & $51^{\circ} 24^{\prime} \mathrm{N}, 5^{\circ} 27^{\prime} \mathrm{E}$ & T1A, T3B \\
\hline 16 & Voroshazi, E. & IMEC (Belgiu m) & $50^{\circ} 51^{\prime} \mathrm{N}, 4^{\circ} 40^{\prime} \mathrm{E}$ & T1A, T1B \\
\hline 17 & Lira-Cantu, M. & CIN2, CSIC, (Spain) & $41^{\circ} 30^{\prime} \mathrm{N}, 2^{\circ} 5^{\prime} \mathrm{E}$ & $\mathrm{T} 1 \mathrm{~B}, \mathrm{~T} 3 \mathrm{~B}$ \\
\hline 18 & Rath, T. & TU Graz, (Austria) & $47^{\circ} 4^{\prime} \mathrm{N}, 15^{\circ} 27^{\prime} \mathrm{E}$ & $\mathrm{T} 1 \mathrm{~A}, \quad \mathrm{~T} 1 \mathrm{~B}, \quad \mathrm{~T} 2$, \\
\hline 19 & Kim, K. & KIST (Korea) & $37^{\circ} 36^{\prime} \mathrm{N}, 127^{\circ} 2^{\prime} \mathrm{E}$ & $\mathrm{T} 1 \mathrm{~A}, \mathrm{~T} 2, \mathrm{~T} 3 \mathrm{~B}$ \\
\hline 20 & Katz. E \& Manor, & BGU (Israel) & $37^{\circ} 51^{\prime} \mathrm{N}, 34^{\circ} 46^{\prime} \mathrm{E}$ & T3A \\
\hline 21 & Watkins, S. & CSIRO (Newcastle, Australia) & $32^{\circ} 53^{\prime} \mathrm{S}, 151^{\circ} 44^{\prime} \mathrm{E}$ & $\mathrm{T} 1 \mathrm{~A}, \quad \mathrm{~T} 1 \mathrm{~B}, \quad \mathrm{~T} 2$, \\
\hline 21 & Watkins, S. & CSIRO(Melbourne, Australia) & $37^{\circ} 54^{\prime} \mathrm{S}, 145^{\circ} 8^{\prime} \mathrm{E}$ & $\begin{array}{lll}\text { T1A, } & \text { T2, } & \text { T3A, } \\
\end{array}$ \\
\hline 22 & Krebs, & Ris $\varnothing$ DTU (Den mark) & $55^{\circ} 41^{\prime} \mathrm{N}, 12^{\circ} 6^{\prime} \mathrm{E}$ & $\mathrm{T} 1 \mathrm{~A}, \quad \mathrm{~T} 1 \mathrm{~B}, \mathrm{~T} 2$, \\
\hline
\end{tabular}

* ASTM standard tests: EMMAQUA, Desert Weathering, Inland Weathering. The performance of the modules was only measured at Risø DTU before and after storage at ATLAS 


\subsubsection{Encapsulation and performance variability of the calibrated modules}

As mentioned in the experimental section each package contained a calibrated device, which was carefully measured at Ris $\varnothing$ DTU under both indoor and outdoor conditions prior to shipping and the recipient groups were asked to carry out similar performance measurement. The purpose of this study was firstly, to quantify the ability of the groups to perform accurate performance measurement and secondly, to compare the results with previously reported ILS studies of R2R manufactured OPV modules [1]. While the solar cells employed in this study were encapsulated the encapsulation was not complete to allow for some degradation to be observed over the 1000 hours that the experiments were intended to endure. A fully edge sealed version of these solar cell modules is expected to present significantly better stability.

Measurements at RisфDTU: A correlation between outdoor and indoor measurements of the calibrated modules at Ris $\varnothing$ DTU revealed that cell performance inside is $\sim 3 / 4$ of the performance outside as shown in Figure 4. This was attributed to a high sensitivity of performance to UV content due to the photoconductivity of the $\mathrm{ZnO}$ layer. The outdoor spectrum is known to be richer in the high energy UV-region (190-290 nm) than that of the KHS 575, and this was cited as the reason for the performance increase outdoors. Furthermore, the lower temperature may affect the performance [1]. It is worth noting that there is some spread around the fitted line plotted in Figure 4; this is attributed to inaccuracies in the estimation of the solar 
intensity outdoors due to cloud cover and differences in temperature fluctuations. The spread would likely be decreased by performing repeated measurements outdoors to obtain good statistics, but this was not practical due to a lack of consistent sunlight in Denmark during the time the study was prepared.

Figure 4. Correlations between outdoor and indoor (red triangles) characterizations at Ris $\varnothing$ DTU.

Calibrated Testing Across Labs: 19 groups reported results of measurements of calibrated devices. Table 7 shows the list of the groups together with the date of measurement and the measured PV parameters. Various light sources used for measurements have been reported by the recipient laboratories including real sun in some cases (listed in the table 7). Each group performed measurements under either indoor or outdoor conditions. Figure 5 presents the PV parameters, plotted as Ris $\varnothing$ DTU Indoor/Outdoor versus Recipient Laboratory.

Table 7. The list of laboratories, the date of measurement and the measured photovoltaic parameters for calibrated modules.

\begin{tabular}{|c|c|c|c|c|c|c|l|l|}
\hline $\begin{array}{c}\text { Packa } \\
\text { ge } \\
\begin{array}{c}\text { Numb } \\
\text { er }\end{array}\end{array}$ & Laboratory & $\begin{array}{c}\text { Meas } \\
\text { Date }\end{array}$ & $\begin{array}{c}\text { Light } \\
\text { Source }\end{array}$ & $\begin{array}{c}\text { Light } \\
\text { Intensi } \\
\text { ty }(\mathrm{W} \\
\left.\mathrm{m}^{-2}\right)\end{array}$ & $\begin{array}{c}\text { Samp } \\
\text { le } \\
\text { Tem } \\
\mathrm{p} .\end{array}$ & $\begin{array}{c}\text { Ris } \emptyset \text { DTU } \\
\text { indoor } \\
\left(\mathrm{I}_{\text {sc }} / \mathrm{V}_{\text {oc }}\right. \\
\text { FF/PCE) }\end{array}$ & $\begin{array}{c}\text { Ris DTU } \\
\text { Outdoor }\end{array}$ & Recipient \\
\hline 1 & $\begin{array}{c}\text { Riede, M. } \\
\text { (Stanford) }\end{array}$ & $\begin{array}{c}18 / 0 \\
6\end{array}$ & $\begin{array}{c}\text { Outdoor } \\
\text { (Sun) }\end{array}$ & 942 & 20 & $\begin{array}{l}9.6 / 8.1 / 50 \\
/ 1.1\end{array}$ & $\begin{array}{l}11.4 / 8.6 / 5 \\
9 / 1.6\end{array}$ & $\begin{array}{l}11.2 / 8.7 / 55 \\
/ 1.5\end{array}$ \\
\hline 2 & $\begin{array}{c}\text { Katz, E. } \\
\text { (BGU) }\end{array}$ & $\begin{array}{c}08 / 0 \\
6\end{array}$ & $\begin{array}{c}\text { Outdoor } \\
\text { (Sun) }\end{array}$ & - & 41 & $\begin{array}{l}9.8 / 8.4 / 51 \\
/ 1.2\end{array}$ & $\begin{array}{l}11.3 / 8.7 / 5 \\
3 / 1.5\end{array}$ & $\begin{array}{l}10.5 / 8.6 / 53 \\
/ 1.4\end{array}$ \\
\hline 4 & $\begin{array}{c}\text { Voroshazi, } \\
\text { E. (IMEC) }\end{array}$ & $\begin{array}{c}25 / 0 \\
5\end{array}$ & $\begin{array}{c}\text { Abet 3000 } \\
\text { Class AAA }\end{array}$ & 1000 & 75 & $\begin{array}{l}10.4 / 8.2 / 4 \\
9 / 1.2\end{array}$ & $\begin{array}{l}11.9 / 8.7 / 5 \\
2 / 1.5\end{array}$ & $\begin{array}{l}10.3 / 8.1 / 58 \\
/ 1.5\end{array}$ \\
\hline
\end{tabular}




\begin{tabular}{|c|c|c|c|c|c|c|c|c|}
\hline & & & Simulator & & & & & \\
\hline 5 & $\begin{array}{l}\text { Galagan, } \\
\text { Y.O. (Holst } \\
\text { Center) }\end{array}$ & - & $\begin{array}{c}\text { AM1.5 } \\
\text { Simulator }\end{array}$ & 1000 & 25 & $\begin{array}{l}9.6 / 8.5 / 49 \\
/ 1.1\end{array}$ & $\begin{array}{l}11.5 / 8.8 / 5 \\
2 / 1.5\end{array}$ & $\begin{array}{l}7.9 / 6.9 / 41 / \\
0.6\end{array}$ \\
\hline 6 & $\begin{array}{c}\text { Shrotriya, } \\
\text { V. } \\
\text { (Solarmer) }\end{array}$ & $\begin{array}{c}01 / 0 \\
6\end{array}$ & $\begin{array}{c}\text { Oriel Solar } \\
\text { Simulator } \\
\text { Model } \\
91190\end{array}$ & 1000 & 55 & $\begin{array}{l}8.3 / 7.6 / 53 \\
/ 1\end{array}$ & $\begin{array}{l}11.5 / 8.7 / 5 \\
4 / 1.5\end{array}$ & $\begin{array}{l}9.5 / 8.4 / 54 / \\
1.2\end{array}$ \\
\hline 7 & $\begin{array}{c}\text { Lira-Cantu, } \\
\text { M. (CIN2, } \\
\text { CSIC) }\end{array}$ & $\begin{array}{c}29 / 0 \\
5\end{array}$ & - & 1000 & 46 & $\begin{array}{l}9.8 / 8.1 / 44 \\
/ 1\end{array}$ & $\begin{array}{l}11.2 / 8.3 / 4 \\
7 / 1.2\end{array}$ & $\begin{array}{l}9.8 / 8.1 / 33 / \\
0.7\end{array}$ \\
\hline 9 & $\begin{array}{l}\text { Hermenau, } \\
\text { M. (IAPP) }\end{array}$ & $\begin{array}{c}28 / 0 \\
5\end{array}$ & - & 1000 & 50 & $\begin{array}{l}9.8 / 7.6 / 44 \\
/ 0.9\end{array}$ & $\begin{array}{l}11.8 / 8.2 / 4 \\
8 / 1.3\end{array}$ & $\begin{array}{l}14.5 / 7.8 / 50 \\
/ 1.6\end{array}$ \\
\hline 10 & $\begin{array}{c}\text { Hoppe, H. } \\
\text { (TU } \\
\text { Ilmenau) }\end{array}$ & $\begin{array}{c}28 / 0 \\
5\end{array}$ & $\begin{array}{c}\text { class B } \\
\text { solar } \\
\text { simulator }\end{array}$ & - & - & $\begin{array}{l}9.8 / 8.3 / 50 \\
/ 1.1\end{array}$ & $\begin{array}{l}\text { 11.4/8.7/4 } \\
9 / 1.4\end{array}$ & $8 / 8.3 / 54 / 1$ \\
\hline 11 & $\begin{array}{l}\text { Lloyd, M. } \\
\text { (NREL) }\end{array}$ & $\begin{array}{c}11 / 0 \\
6\end{array}$ & $\begin{array}{c}\text { AM1.5 } \\
\text { Simulator }\end{array}$ & 1000 & - & $\begin{array}{l}10 / 8.7 / 47 / \\
1.2\end{array}$ & $\begin{array}{l}11.8 / 9.2 / 5 \\
2 / 1.6\end{array}$ & $\begin{array}{l}9.5 / 8.7 / 46 / \\
1.1\end{array}$ \\
\hline 12 & $\begin{array}{c}\text { Xiao, M. } \\
\text { (Plextronics } \\
\text { ) }\end{array}$ & $\begin{array}{c}28 / 0 \\
5\end{array}$ & $\begin{array}{c}\text { Newport } \\
\text { Oriel } \\
91194- \\
1000 \\
\end{array}$ & 1000 & - & $\begin{array}{l}10.4 / 6.8 / 4 \\
3 / 0.9\end{array}$ & $\begin{array}{l}12 / 7.9 / 48 / \\
1.3\end{array}$ & $\begin{array}{l}10.1 / 6.6 / 30 \\
/ 0.6\end{array}$ \\
\hline 14 & $\begin{array}{l}\text { Rath, T. } \\
\text { (TU Graz) }\end{array}$ & $\begin{array}{c}31 / 0 \\
5\end{array}$ & - & - & 55 & $\begin{array}{l}9.2 / 8.6 / 53 \\
/ 1.2\end{array}$ & $\begin{array}{l}11.1 / 9.2 / 5 \\
5 / 1.6\end{array}$ & $\begin{array}{l}10 / 8.8 / 52 / 1 \\
.3\end{array}$ \\
\hline 16 & $\begin{array}{l}\text { Watkins, S. } \\
\text { (CSIRO, } \\
\text { Melbourne) }\end{array}$ & $\begin{array}{c}28 / 0 \\
5\end{array}$ & $\begin{array}{l}\text { Newport- } \\
\text { Oriel solar } \\
\text { simulator } \\
\text { (AM1.5 } \\
\text { filters) }\end{array}$ & 1000 & - & $\begin{array}{l}10 / 8.3 / 53 / \\
1.2\end{array}$ & $\begin{array}{l}11.9 / 8.7 / 5 \\
5 / 1.6\end{array}$ & $\begin{array}{l}11.3 / 8.6 / 42 \\
/ 1.2\end{array}$ \\
\hline 16 & $\begin{array}{c}\text { Watkins, S. } \\
\text { (CSIRO, } \\
\text { Newcastle) }\end{array}$ & $\begin{array}{c}02 / 0 \\
6\end{array}$ & $\begin{array}{l}\text { Newport- } \\
\text { Oriel solar } \\
\text { simulator } \\
\text { (AM1.5 } \\
\text { filters) }\end{array}$ & 1000 & 58 & $\begin{array}{l}10 / 8.3 / 53 / \\
1.2\end{array}$ & $\begin{array}{l}11.9 / 8.7 / 5 \\
5 / 1.6\end{array}$ & $\begin{array}{l}10.6 / 8.5 / 46 \\
/ 1.2\end{array}$ \\
\hline 18 & $\begin{array}{l}\text { Kim, K. } \\
\text { (KIST) }\end{array}$ & $\begin{array}{c}30 / 0 \\
5\end{array}$ & - & - & 34 & $\begin{array}{l}9.6 / 8.1 / 48 \\
/ 1\end{array}$ & $\begin{array}{l}11.5 / 8.5 / 4 \\
8 / 1.3 \\
\end{array}$ & $\begin{array}{l}11.1 / 8.8 / 40 \\
/ 1.1\end{array}$ \\
\hline 19 & $\begin{array}{l}\text { Swonke, T } \\
\text { (ZAE) }\end{array}$ & - & $\begin{array}{c}\text { Newport } \\
94061 \mathrm{~A} \\
\text { Sol1A } \\
\text { (ABA) } \\
\end{array}$ & 1000 & 68 & $\begin{array}{l}9.8 / 8.5 / 50 \\
/ 1.2\end{array}$ & $\begin{array}{l}11.3 / 8.9 / 4 \\
9 / 1.4\end{array}$ & $\begin{array}{l}12.6 / 8.6 / 53 \\
/ 1.6\end{array}$ \\
\hline 21 & $\begin{array}{c}\text { Schwartz, } \\
\text { G. } \\
\text { (Heliatek) }\end{array}$ & - & $\begin{array}{c}\text { Steuernagel } \\
\text { SC1200 }\end{array}$ & 1000 & 34 & $\begin{array}{l}9.8 / 8.2 / 48 \\
/ 1.1\end{array}$ & $\begin{array}{l}11.4 / 8.6 / 5 \\
2 / 1.4\end{array}$ & $\begin{array}{l}11.7 / 4.1 / 32 \\
/ 0.4\end{array}$ \\
\hline 22 & $\begin{array}{c}\text { Elschner, } \\
\text { A. (H.C. } \\
\text { Starck) }\end{array}$ & - & $\begin{array}{c}\text { Atlas Solar } \\
\text { Cell test } \\
575\end{array}$ & 1000 & 75 & $\begin{array}{l}10.2 / 8.2 / 4 \\
9 / 1.2\end{array}$ & $\begin{array}{l}11.8 / 8.6 / 5 \\
4 / 1.5\end{array}$ & $\begin{array}{l}10.3 / 8.2 / 49 \\
/ 1.2\end{array}$ \\
\hline 23 & $\begin{array}{l}\text { Veenstra, } \\
\text { S.C. (ECN) }\end{array}$ & $\begin{array}{c}03 / 0 \\
6\end{array}$ & - & 1000 & 65 & $\begin{array}{l}9.7 / 7.8 / 43 \\
/ 0.9\end{array}$ & $\begin{array}{l}11.9 / 8.7 / 4 \\
6 / 1.3\end{array}$ & $\begin{array}{l}8.7 / 8.2 / 43 / \\
0.9\end{array}$ \\
\hline 25 & $\begin{array}{l}\text { Hauch, J. } \\
\text { (Konarka) }\end{array}$ & - & - & - & 65 & $\begin{array}{l}9.6 / 8.2 / 51 \\
/ 1.1\end{array}$ & $\begin{array}{l}11.2 / 8.6 / 5 \\
4 / 1.5\end{array}$ & $\begin{array}{l}10.9 / 8.8 / 50 \\
/ 1.3\end{array}$ \\
\hline $\begin{array}{l}\text { All/ } \\
\text { indoor }\end{array}$ & Ris $\varnothing$ DTU & $\begin{array}{c}14 / 0 \\
5\end{array}$ & $\begin{array}{c}\text { Steuernagel } \\
\text { SC } 575\end{array}$ & 1000 & $\begin{array}{c}75( \pm \\
5)\end{array}$ & - & - & - \\
\hline
\end{tabular}




\begin{tabular}{|c|c|c|c|c|c|c|c|c|}
\hline $\begin{array}{c}\text { All/ } \\
\text { Outdo } \\
\text { or }\end{array}$ & Risø DTU & $\begin{array}{c}17 / 0 \\
5\end{array}$ & Real Sun & $\begin{array}{c}950( \pm \\
50)\end{array}$ & - & - & - & \\
\hline
\end{tabular}
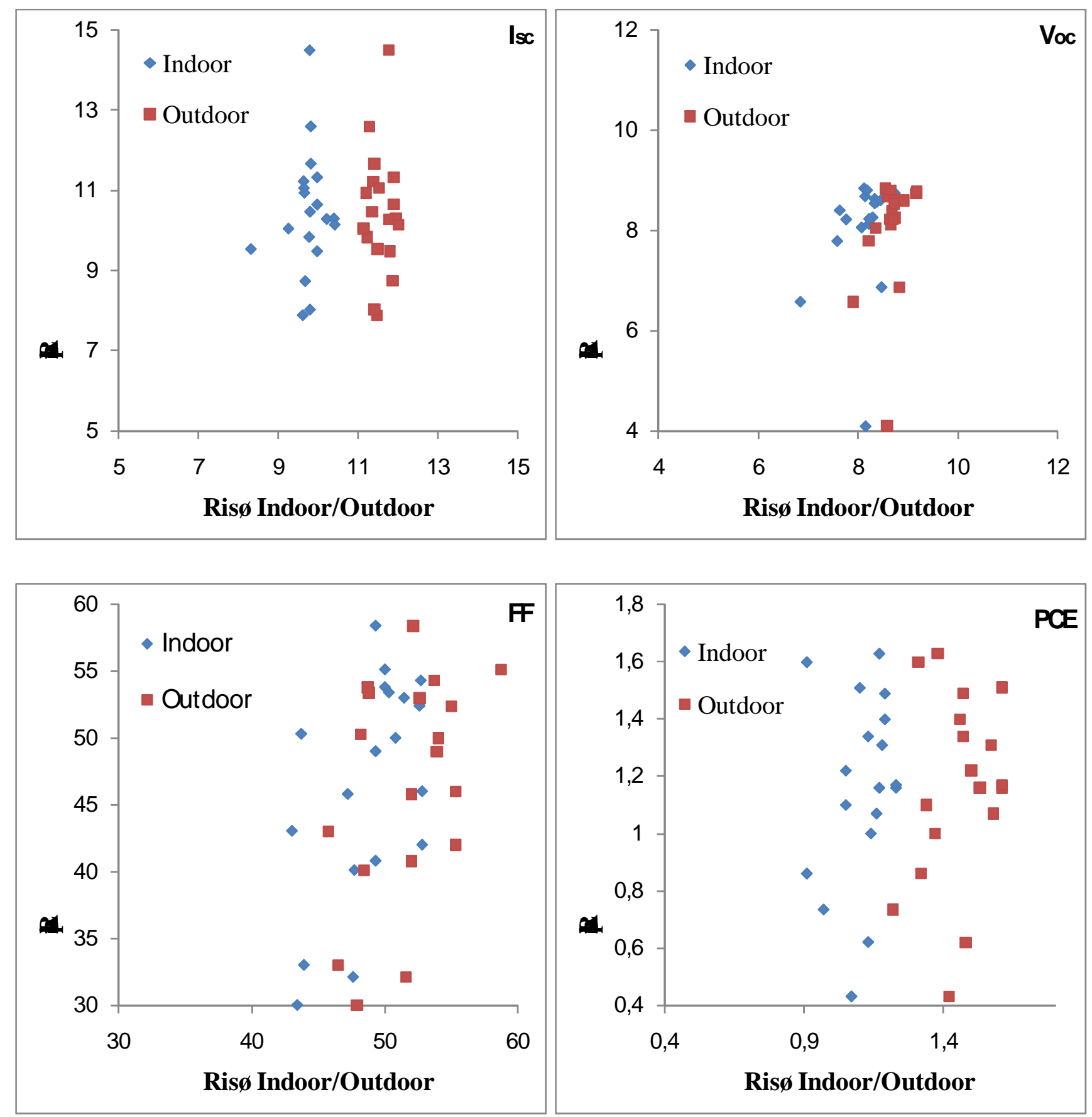
Figure 5. The spread of $I_{s c}, V_{o c}, F F$ and PCE for calibrated modules. Red rectangles correspond to outdoor and blue rhombs to indoor measurements performed at Ris $\varnothing$ DTU.

Table 8 shows the average values and in parentheses the standard deviations (SD) as a percentage of the average value. While the SDs of data measured at Risø DTU were essentially within $10 \%$ the spread between recipient labs was up to $15 \%$ for $\mathrm{I}_{\mathrm{sc}}$ and $\mathrm{V}_{\mathrm{oc}}, 18 \%$ for FF and $31 \%$ for PCE. If the obvious outliers observed in the plots of $\mathrm{V}_{\text {oc }}$, FF and PCE are excluded then the SDs of recipient lab decrease for $\mathrm{V}_{\text {oc }}$ to $3.6 \%$, FF to $11.4 \%$ and PCE to $22.8 \%$.

Table 8. List of average values with $\mathrm{SDs}$ as a percent of average values in parentheses.

\begin{tabular}{|c|c|c|c|}
\hline Parameter & Ris $\emptyset$ Outdoor & Ris $\emptyset$ Indoor & Recipient Laboratory \\
\hline $\mathrm{I}_{\mathrm{sc}}(\mathrm{mA})$ & $11.6( \pm 2.4 \%)$ & $9.7( \pm 4.6 \%)$ & $10.5( \pm 14.6 \%)$ \\
\hline $\mathrm{V}_{\mathrm{oc}}(\mathrm{V})$ & $8.6( \pm 3.3 \%)$ & $8.1( \pm 5.3 \%)$ & $8( \pm 14.1 \%)^{*}$ \\
\hline $\mathrm{FF}(\%)$ & $51.6( \pm 6.7 \%)$ & $48( \pm 6.8 \%)$ & $46( \pm 18 \%)^{*}$ \\
\hline $\mathrm{PCE}(\%)$ & $1.45( \pm 8.3 \%)$ & $1.1( \pm 10 \%)$ & $1.12( \pm 31 \%)^{*}$ \\
\hline
\end{tabular}

*Without outliers the standard deviations would be $\mathrm{V}_{\text {oc }}-3,6 \%$, FF $-11.4 \%$ and PCE - $22.8 \%$

One can also observe that the average values of measurements at recipient labs is rather close to Ris $\varnothing$ DTU under indoor conditions, while the outdoor measurements at Risø DTU yield slightly higher values (due to earlier discussed reasons). Two groups (in Sede Boqer, Israel and Stanford, US) out of the 19 measured the cells using real sun and the average of two measurements $\left(I_{\mathrm{sc}}=10.9 \mathrm{~mA} ; \mathrm{V}_{\mathrm{oc}}=8.6 \mathrm{~V} ; \mathrm{FF}=\right.$ $54 \% ; \mathrm{PCE}=1.45 \%$ ) are rather close to outdoor results at Ris $\varnothing$ DTU. Although, there 
is not enough outdoor data for making firm conclusions, this could, to some extent, suggest that most of the indoor measurements are carried out under artificial light sources with lower UV content compared to real AM1.5G, which results in poorer module performance due to high sensitivity of these particular devices towards UV light content. This can probably be generalized to many other types of OPV devices, which are sensitive to spectral distribution. This could mean that the performance for such a class of OPV devices is underestimated.

Such a mismatch can be overcome by simply using simulators with spectral distribution very close to real sun irradiation spectrum not only at visible wavelength range, but also for IR and UV. Another solution can be, if accurate measurements are performed using both an indoor light source and outdoor real sun irradiation at the same time.

Comparison to Previous ILS: Table 9 compares the values of SDs (in percent of average values) of the current results with previous ILS studies [1]. Clearly, there is a significant improvement in reproducibility of the performance of different modules in this set of samples compared to the samples prepared in the previous ILS study. A number of issues concluded from the previous ILS studies have been addressed during the production of these modules, which obviously improved the reproducibility. In particular:

- A more compact geometry was chosen in this case with a module size of 12 $\mathrm{cm} \times 8.5 \mathrm{~cm}$ and required illumination area of $7.4 \mathrm{~cm} \times 7.9 \mathrm{~cm}$, which eased 
the uniform illumination of the samples in the different laboratories (previous module dimensions were $25 \mathrm{~cm} \mathrm{x} 10,7 \mathrm{~cm}$ ).

- Male and female buttons were introduced for contacting the electrodes, which proved to be a rather stable contacting technique which reduced any fluctuations caused by electrical contact problems.

- A laser-cut mask was used for masking the modules, which improved the accuracy of the measurements.

- Detailed instructions of measurement procedure and the dynamic behavior of the sample performance were provided in the protocol together with the cells. Although the spread of $\mathrm{V}_{\mathrm{oc}}$, FF and PCE for the recipient laboratories are larger in the new studies the extracting of the obvious outliers significantly improves the picture and only the spread in FF slightly exceeds the spread of previous data (values without outliers are shown in parentheses in Table 9). The outliers and the rather large spread of FF value at recipient labs are attributed mainly to the earlier discussed inflection point [14].

Table 9. Comparison of SD values as a percent of average values for this and previous ILS.

\begin{tabular}{|c|c|c|c|c|}
\hline Parameter & $\begin{array}{c}\text { Ris } \emptyset \text { DTU } \\
\text { (Previous ILS) }\end{array}$ & $\begin{array}{c}\text { Ris } \varnothing \text { DTU } \\
\text { (New ILS) }\end{array}$ & $\begin{array}{c}\text { Recipient } \\
\text { (Previous ILS) }\end{array}$ & $\begin{array}{c}\text { Recipient } \\
\text { (New ILS) }\end{array}$ \\
\hline $\mathrm{I}_{\mathrm{sc}}$ & $8.6 \%$ & $4.6 \%$ & $28 \%$ & $14.6 \%$ \\
\hline $\mathrm{V}_{\mathrm{oc}}$ & $8.9 \%$ & $5.3 \%$ & $9.2 \%$ & $14.1 \%(3.6 \%)^{*}$ \\
\hline $\mathrm{FF}$ & $10.1 \%$ & $6.8 \%$ & $9.7 \%$ & $18 \%(11.4 \%)^{*}$ \\
\hline $\mathrm{PCE}$ & $22 \%$ & $10 \%$ & $26.8 \%$ & $31 \%(22.8 \%)^{*}$ \\
\hline
\end{tabular}

*The values in the parentheses are the standard deviations for Recipient (New RR) without the outliers 
Conclusions of Calibrated Studies: The studied modules proved to be rather sensitive to the spectral distribution and especially to the UV quantity of the light used for the measurements. This resulted in variation of photovoltaic response of the devices measured in indoor and outdoor conditions. In all cases the outdoor measurements showed nearly $25 \%$ better performance, which is due to the fact that the most light sources used among laboratories have lower UV content compared to real sun. Therefore, when a careful quantification of OPV device of such a type is required, one has to take special care of the spectral distribution of the light source to be used for the studies. Ideally, characterization of the device under both indoor and outdoor conditions can solve the problem.

\subsubsection{Shelf Life Studies (T1A)}

The purpose of T1A was to establish if it is possible to compare shelf life of modules across groups within reasonable data deviations. In this case, the samples are usually stored in a dark in an ambient room environment, such as for example drawer and the variability of the environmental conditions across different laboratories is minimal compared to other stability studies. Thus, the T1 test can give a good insight into how much the handling of the samples and the specific ways of periodic measurements at different laboratories can contribute in the spread of data.

Variations Across Labs: 18 groups shown in Table 10 reported on shelf life studies for total of 32 ST type modules and 15 of 3 other types (see table 1). The received data were mostly text or excel files with raw IV-curve data and sheets of time vs. 
photovoltaic parameters extracted from IV curves. Measurements periodicity varied among the groups.

Table 10. The list of laboratories for T1A studies. The starting date of the experiment, temperature and RH ranges are listed as well.

\begin{tabular}{|c|c|c|c|c|c|}
\hline Package & Laboratory & Starting & Sample & Storage & Storage R.H. \\
\hline 4 & Voroshazi, E. (IMEC) & $01 / 06$ & 2 & 20 & $30-40$ \\
\hline 5 & Galagan, Y.O. (Holst & - & 2 & 25 & - \\
\hline 6 & Shrotriya, V. (Solarmer) & $01 / 06$ & 5 & $23-29$ & $36-48$ \\
\hline 9 & Hermenau, M. (IAPP) & $31 / 05$ & 6 & - & - \\
\hline 10 & Hoppe, H. (TU Ilmenau) & $28 / 05$ & 1 & - & - \\
\hline 11 & Lloyd, M. (NREL) & $11 / 06$ & 1 & - & - \\
\hline 12 & Xiao, M. (Plextronics) & $28 / 05$ & 2 & - & - \\
\hline 14 & Rath, T. (TU Graz) & $31 / 05$ & 6 & - & - \\
\hline 16 & Watkins, S. (CSIRO, & $01 / 06$ & 3 & - & - \\
\hline 16 & Watkins, S. (CSIRO, & $01 / 06$ & 1 & $12-27$ & $34-88$ \\
\hline 17 & Zimmerman, B. (ISE) & $31 / 05$ & 2 & - & - \\
\hline 18 & Kim, K. (KIST) & $30 / 05$ & 4 & 24 & 42 \\
\hline 19 & Swonke, T (ZAE) & $31 / 05$ & 1 & 27 & 44 \\
\hline 21 & Schwartz, G. (Heliatek) & - & 1 & 27 & 35 \\
\hline 22 & Elschner, A. (H.C. Starck) & $28 / 05$ & 5 & 22 & - \\
\hline 23 & Veenstra, S.C. (ECN) & - & 1 & - & - \\
\hline 25 & Hauch, J. (Konarka) & - & 3 & - & - \\
\hline 26 & Ris $\varnothing$ DTU & $31 / 05$ & 1 & $18-26$ & $\leqslant 45$ \\
\hline
\end{tabular}

The first attempts of defining quantities, such as burn in range, initial stabilized efficiency $\mathrm{PCE}_{0} \mathrm{~s}$ and $\mathrm{T} 80$ (time when device degrades to $80 \%$ of optimum performance), as suggested in the protocol of ISOS-2 [17] led to no success. The dynamic nature of the photovoltaic response for this type of cell was too diverse and in most cases the frequency of measured data was in the same range with the time resolution of the dynamic changes, which made it rather difficult to determine these quantities. As a consequence the data were chosen to be processed and presented as follows. We discuss here the case of PCE, but the same approach was applied to all photovoltaic parameters ( $I_{s c}, V_{o c}, F F$ and PCE). Decay curves of PCE versus time were plotted and normalized to the maximum values $\left(\mathrm{PCE}_{\max }\right)$. The normalized values at 5 
different time points $\left(\mathrm{t}_{0}, \mathrm{t}_{200}, \mathrm{t}_{400}, \mathrm{t}_{700}\right.$ and $\left.\mathrm{t}_{1000}\right)$ were extracted from each curve and summarized in the general plot. Average values and SDs were calculated for each time point. Figure 6 presents the calculated values together with the average values intersected by a dashed line for guiding the eye and the error bars showing the SDs. Red triangles show the outliers (not included in calculation of average and SD), which are attributed to catastrophic failure of the device probably induced by the handling. Most of the samples suffered from the presence of an initial inflection point and therefore, PCE had low values at $t_{0}$. Thus, all the original curves were chosen to be normalized to $\mathrm{PCE}_{\max }$ at $\mathrm{t}_{\mathrm{max}}$ and an average of $\mathrm{t}_{\max }$ across the laboratories was calculated and set as an additional time point for the average curve. $t_{\max }$ was in the range of the first 40 hours (different for the different photovoltaic parameters). However, $t_{\max }$ can be underestimated, since changes in the curves could easily happen within an interval between two measurements and thus could not be recorded. The uncertainty of $t_{\max }$ can significantly contribute to the spread of general data, since all the degradation curves are normalized to the corresponding PCE max $_{\text {for }}$ each laboratory. We chose however, to compare the $\mathrm{PCE}(\mathrm{t})$ values (performance at a given time point) rather than the lifetime values, such as T80, because the T80 parameter is much more strongly affected by the uncertainty of $t_{\text {max }}$ than the values of $\operatorname{PCE}(t)$. 

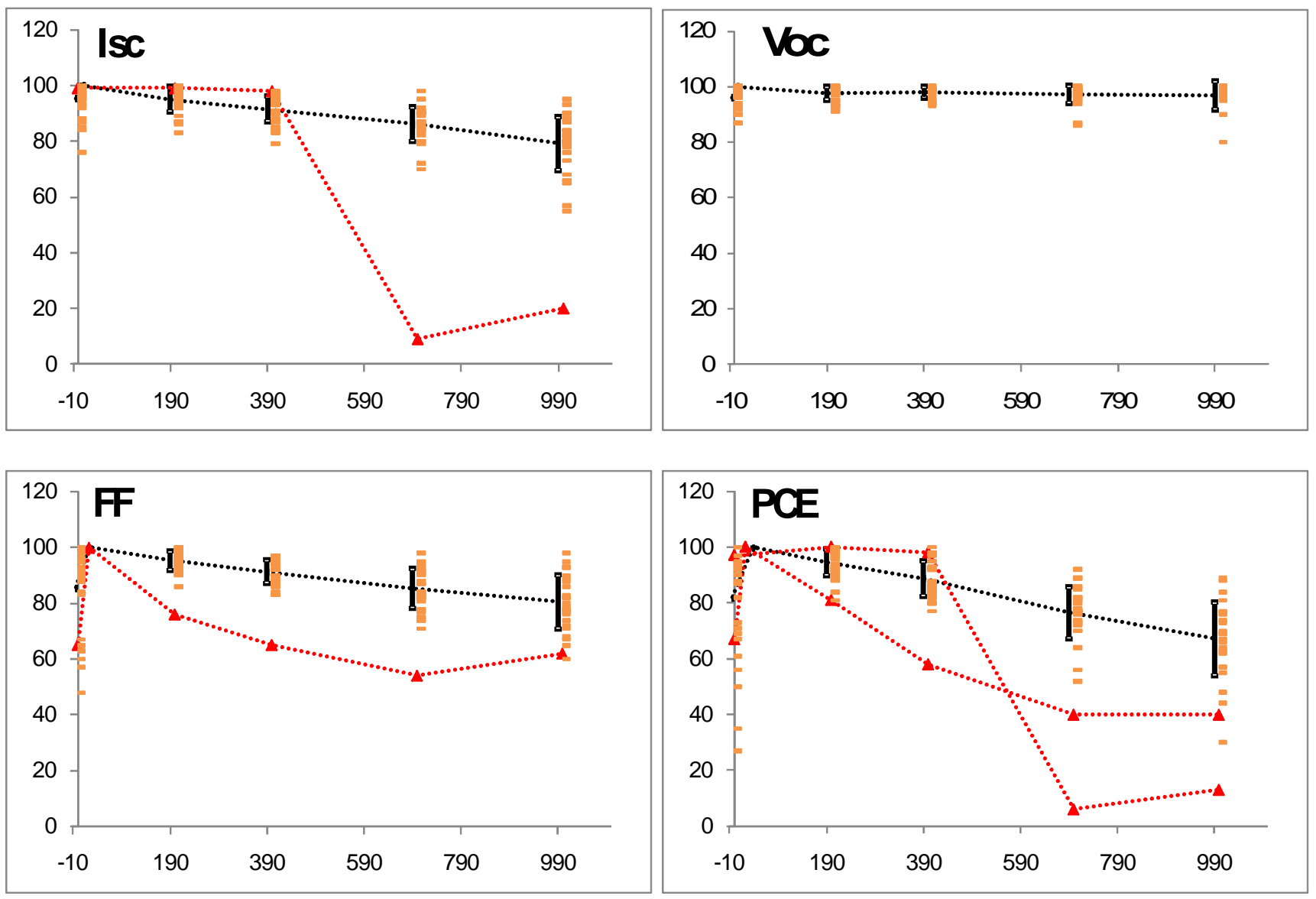

\begin{tabular}{|c|c|}
\hline Parameter & Range \\
\hline Storage Temperature & $12-29{ }^{\circ} \mathrm{C}$ \\
\hline Relative Humidity & $30-48 \%$ \\
\hline Starting Date & $28 / 05-11 / 06$ \\
\hline T80 for Average PCE & $\sim 615 \mathrm{hrs}$ \\
\hline
\end{tabular}

Figure 6. Variation of PV parameters across the time measured on 29 modules (orange rectangles). The parameters are normalized to maximal values. Horizontal axes represent the time (hrs). The dashed line intersects the average values and the error bars represent the SDs. Red triangles show the outliers connected with dashed lines for guiding the eye (outliers were excluded in calculations of average).

The plots in figure 6 only show results for ST type modules, as the inflection point effect was less pronounced in this type of cells. The other 3 types can be found in the supporting information. The reported data for 3 modules out of 32 were categorized as "unreadable" (discussed in section 3.9) and were not included in the 
calculations. The range of temperature and relative humidity (RH), if measured during testing, are shown in the table in figure 6 together with the range of the starting dates. The average T80 for PCE is shown as well, which is about 615 hours if calculated from $t_{0}$. If $t_{\max }$ is taken as the starting point then $\mathrm{T} 80$ is about 580 hours. For the most stable modules T80 can reach more than $1000 \mathrm{hrs}$.

Table 11 shows the average values of each parameter along the decay together with the SDs. The SDs are increasing along the degradation of the devices probably because of different decay kinetics in different modules, but still remaining below 10 $\%$ for $\mathrm{I}_{\mathrm{sc}}, \mathrm{V}_{\mathrm{oc}}$ and FF and reaching to $13 \%$ for PCE at $\mathrm{t}_{1000}$. There is a difference between normalized values of PCE and the values calculated from normalized values of $I_{s c}, V_{o c}$ and $F F$, which arises from the fact that different maximal values are chosen for normalization of data in both cases.

Table 11. The average of $p v$ parameters at different times and the corresponding SDs.

\begin{tabular}{|c|c|c|c|c|c|c|c|c|}
\hline \multirow{2}{*}{ Time (hrs) } & \multicolumn{2}{|c|}{$\mathrm{I}_{\mathrm{sc}}$ (Normalized) } & \multicolumn{2}{c|}{$\mathrm{V}_{\text {oc }}$ (Normalized) } & \multicolumn{2}{c|}{ FF (Normalized) } & \multicolumn{2}{c|}{ PCE (Normalized) } \\
\cline { 2 - 9 } & Average & SD & Average & SD & Average & SD & Average & SD \\
\hline $\mathrm{t}_{\max }$ & 100 & - & 100 & - & 100 & - & 100 & - \\
\hline 200 & 95 & 4.6 & 97 & 2.6 & 95 & 3.5 & 95 & 4.9 \\
\hline 400 & 91 & 4.6 & 98 & 2.1 & 91 & 4.3 & 89 & 6.4 \\
\hline 700 & 86 & 6 & 97 & 3.3 & 85 & 7.1 & 76 & 9.3 \\
\hline 1000 & 79 & 9.7 & 97 & 5.1 & 80 & 9.8 & 67 & 13.2 \\
\hline
\end{tabular}

Intra-laboratory vs. Inter-laboratory: Some laboratories measured 2 or 3 modules in the same conditions, which allowed a comparison of intra-laboratory and interlaboratory deviations. SDs were calculated (in case of 2 modules simple deviations from the average value were taken) within the same laboratory and averaged over 9 
laboratories and compared to SDs across the same 9 laboratories (total of 22 modules) for 4 time points. Table 12 shows the intra-laboratory and interlaboratory $\mathrm{SD}$ (averaged over 4 time points) for 9 labs and the ratio between these two in percent. The results show that a large portion of data-spread within the laboratories is a result of deviations within the modules. The numbers are different for different time points and thus the averages over 4 time points are shown here. It is worth mentioning that in some cases variations within data from the particular laboratory were exceeding the variations across all laboratories (probably due to handling/mechanical stresses, which can be detrimental for device performance).

Table 12. Intra-lab and Inter-lab SD values averaged for 4 time points and their ratio in percent.

\begin{tabular}{|c|c|c|c|c|}
\hline SD & $\mathrm{I}_{\mathrm{sc}}$ & $\mathrm{V}_{\mathrm{oc}}$ & $\mathrm{FF}$ & PCE \\
\hline Inter-Laboratory & 5.5 & 3.6 & 5.9 & 8.4 \\
\hline Intra-Laboratory & 2.4 & 1.9 & 3.6 & 4.4 \\
\hline Ratio & $48 \%$ & $55 \%$ & $61 \%$ & $51 \%$ \\
\hline
\end{tabular}

Conclusions: Overall, the conclusions for this experiment are the following:

- The dynamic changes of photovoltaic response for the tested devices were in the same range with the frequency of the measurements, which introduced large uncertainties in determination of device lifetimes. Quantities such as efficiency at a given time $\operatorname{PCE}(\mathrm{t})$ were more useful in this case.

- The standard deviations of photovoltaics parameters measured on similar modules across 18 laboratories were reaching $13 \%$ after $1000 \mathrm{hrs}$ of shelf life, which can be tolerated assuming the inherent sources of error in this experiment. Additionally, a significant contribution to the spread of data came 
from the photosensitivity of $\mathrm{ZnO}$ in the device. As discussed earlier, the photo-doping of the modules can drastically improve the performance and this phenomenon is reproducible. Thus, if a light source with lower UV quantity was used during the measurements or if the devices were not kept under the light source long enough to remove the inflection point, it could lead to deficient photo-annealing of $\mathrm{ZnO}$ and thus appear as degradation of the module.

- Up to $61 \%$ of deviation value across the laboratories could be ascribed to intrinsic differences in the degradation kinetics of modules themselves. In particular cases however, deviations between modules measured in the same laboratory under same conditions could exceed the deviation values among all the laboratories. The reason is ascribed mostly to the sensitivity of the devices to the handling/mechanical stresses.

\subsubsection{Effect of Storage Temperature and Relative Humidity (T1B)}

It is well established that the environmental factors such as temperature and level of relative humidity $(\mathrm{RH})$ have major effects on device degradation kinetics [18-20]. Thus, it is important to choose a number of Temp./RH combinations, which can be optimal for standard testing of OPV modules and can be accepted and steadily used among the groups in the OPV community. The purpose of T1B was to establish the capabilities of various groups in performing Temp./RH controlled tests and perhaps getting an insight into which conditions are the most optimal in terms of 
reproducibility among groups. 13 groups carried out T1B type experiments with total of 38 ST type and 9 of 3 other types of modules. Table 13 shows the list of the groups performing T1B test together with the values of temperature and RH varying in the ranges of $25-85{ }^{\circ} \mathrm{C}$ and $0-85 \%$ correspondingly. The list shows the diversity of the conditions used by the groups. In some cases RH was not recorded/reported, which put some constrains on comparison of data.

Table 13. The list of laboratories for T1B experiment. The starting date of experiment, storage setup and the ranges of temperature and $\mathrm{RH}$ are listed as well.

\begin{tabular}{|c|c|c|c|c|c|c|}
\hline $\begin{array}{l}\text { Package } \\
\text { number }\end{array}$ & Laboratory & $\begin{array}{c}\text { Starting } \\
\text { Date }\end{array}$ & $\begin{array}{l}\text { Sample } \\
\text { quantity }\end{array}$ & Storage Setup & $\begin{array}{c}\text { Storage } \\
\text { Temp. }\end{array}$ & $\begin{array}{c}\text { Storage R.H. } \\
(\%) \\
\end{array}$ \\
\hline 4 & $\begin{array}{l}\text { Voroshazi, E. } \\
\text { (IMEC) }\end{array}$ & $01 / 06$ & $\begin{array}{l}1 \\
1 \\
1 \\
4\end{array}$ & $\begin{array}{c}\text { Glove-Box } \\
\text { Oven } \\
\text { Drawer } \\
\text { (desiccant) } \\
\text { Env. Chamber } \\
\end{array}$ & $\begin{array}{l}25 \\
45 \\
25 \\
45\end{array}$ & $\begin{array}{c}0 \\
0 \\
<5 \\
60\end{array}$ \\
\hline 6 & $\begin{array}{l}\text { Shrotriya, V. } \\
\text { (Solarmer) }\end{array}$ & $01 / 06$ & 2 & $\begin{array}{ll}\text { Tenney } & \text { T6S } \\
\text { temp. } & \text { and } \\
\text { humidity } & \text { test } \\
\text { chamber } & \\
\end{array}$ & 50 & 50 \\
\hline 7 & $\begin{array}{ll}\text { Lira-Cantu, } & \text { M. } \\
(\mathrm{CIN} 2, \text { CSIC }) & \\
\end{array}$ & $29 / 05$ & 6 & Oven & $40-43$ & $15-24$ \\
\hline 9 & $\begin{array}{c}\text { Hermenau, M. } \\
\text { (IAPP) }\end{array}$ & $31 / 05$ & $\begin{array}{l}1 \\
1 \\
\end{array}$ & $\begin{array}{l}\text { Oven } \\
\text { Oven }\end{array}$ & $\begin{array}{l}65 \\
85 \\
\end{array}$ & - \\
\hline 11 & Lloyd, M. (NREL) & $11 / 06$ & $\begin{array}{l}1 \\
1 \\
\end{array}$ & $\begin{array}{l}\text { Env. Chamber } \\
\text { Env. Chamber }\end{array}$ & $\begin{array}{l}45 \\
85 \\
\end{array}$ & $\begin{array}{l}85 \\
85 \\
\end{array}$ \\
\hline 12 & $\begin{array}{c}\text { Xiao, M. } \\
\text { (Plextronics) }\end{array}$ & $28 / 05$ & 2 & Thermotron & 65 & 85 \\
\hline 14 & Rath, T. (TU Graz) & $31 / 05$ & 3 & Oven & 50 & - \\
\hline 16 & $\begin{array}{c}\text { Watkins, S. } \\
\text { (CSIRO, } \\
\text { Newcastle) }\end{array}$ & $01 / 06$ & 1 & Oven & 45 & $8-16$ \\
\hline 19 & Swonke, T (ZAE) & $31 / 05$ & 2 & Oven & 45 & 50 \\
\hline 21 & $\begin{array}{l}\text { Schwartz, G. } \\
\text { (Heliatek) }\end{array}$ & - & $\begin{array}{l}1 \\
1 \\
1 \\
\end{array}$ & $\begin{array}{l}- \\
- \\
-\end{array}$ & $\begin{array}{l}50 \\
85 \\
85 \\
\end{array}$ & $\begin{array}{c}<10 \\
<10 \\
85 \\
\end{array}$ \\
\hline 23 & $\begin{array}{c}\text { Veenstra, S.C. } \\
\text { (ECN) }\end{array}$ & - & $\begin{array}{l}5 \\
2 \\
2 \\
\end{array}$ & Oven & $\begin{array}{l}45 \\
60 \\
85 \\
\end{array}$ & $\begin{array}{l}- \\
- \\
-\end{array}$ \\
\hline 25 & $\begin{array}{l}\text { Hauch, J. } \\
\text { (Konarka) }\end{array}$ & - & $\begin{array}{l}2 \\
3 \\
2 \\
\end{array}$ & $\begin{array}{c}\text { Weather } \\
\text { Chamber } \\
\text { Oven }\end{array}$ & $\begin{array}{l}65 \\
65 \\
85 \\
\end{array}$ & $\begin{array}{c}85 \\
- \\
- \\
\end{array}$ \\
\hline 26 & Ris $\emptyset$ DTU & $31 / 05$ & 1 & Oven & 50 & 25 \\
\hline
\end{tabular}


The way the data was chosen to be processed and presented here was as follows. Degradation of photovoltaic parameters were calculated at 5 time point using approach similar to the previous section and summarized in two plots: decay versus time at different $\mathrm{RH}$, while the temperature was kept in a small range and decay versus time for different temperatures, while RH was kept in a small range. Only ST type devices were chosen to be presented.

Effect or $R H$ : Figure 7 shows the decay of photovoltaic parameters versus time for different RH values. The measurement points are connected by dashed lines for guiding the eye. Only data within the temperature range of $42-50{ }^{\circ} \mathrm{C}$ were chosen to limit the effect of temperature on the cells. Some of the curves are a result of one module measurement and some are averages over 2 or 3 curves (with the same or slightly different temperatures). From the scarcity and diversity of data it was difficult to draw any conclusion among the reports from the different groups. The dependence of degradation on RH was nearly random. However, one point that the groups seemed to agree on was that humidity levels approaching $85 \%$ or higher lead to fast degradation of the module. Such a large variation in data points to the fact that the modules are too vulnerable towards RH changes and therefore, RH needs to be carefully controlled in order to obtain reproducible data for these types of devices. Such a strong sensitivity of the devices towards RH was also ascribed to incomplete encapsulation discussed in earlier sections. 

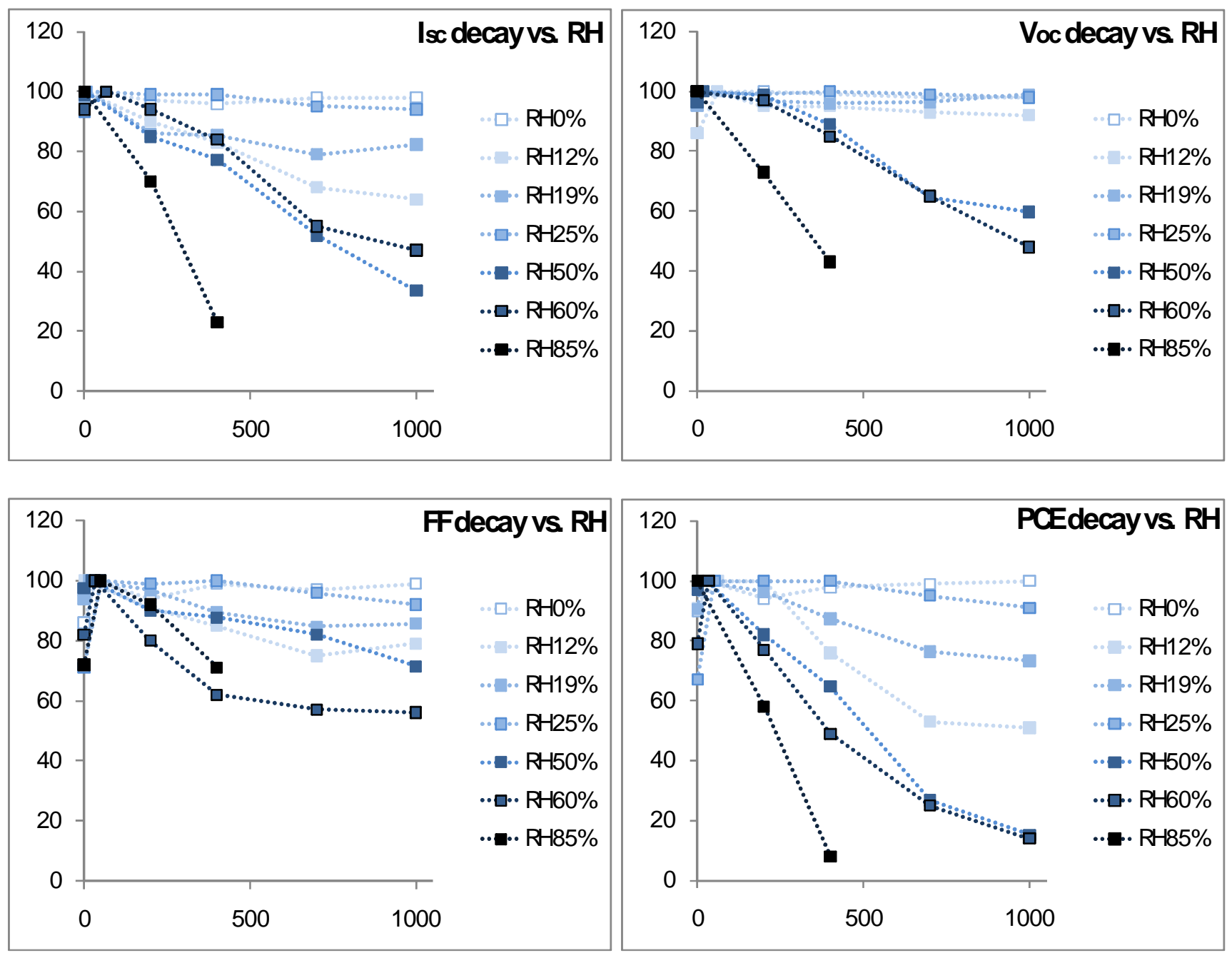

Figure 7. Normalized values of pv parameters vs time (hrs) at different RH levels in the range of $0-85 \%$. The temperature range was $42-50{ }^{\circ} \mathrm{C}$. The measurement points are connected by dashed lines for guiding the eye.

Effect of Temperature: The same approach was applied for performance decay versus time at different temperatures shown in figure 8 . The data were chosen in the $\mathrm{RH}$ range of $20-45 \%$. In this case again $85{ }^{\circ} \mathrm{C}$ lead to a fast degradation of the devices (even in the case of $\mathrm{RH}$ being as low as $5 \%$ ), while temperatures below $65{ }^{\circ} \mathrm{C}$ had a relatively minor effect on the device degradation. The results suggest that the 
modules are less affected by temperature changes (unless extreme temperatures are applied) compared to RH.
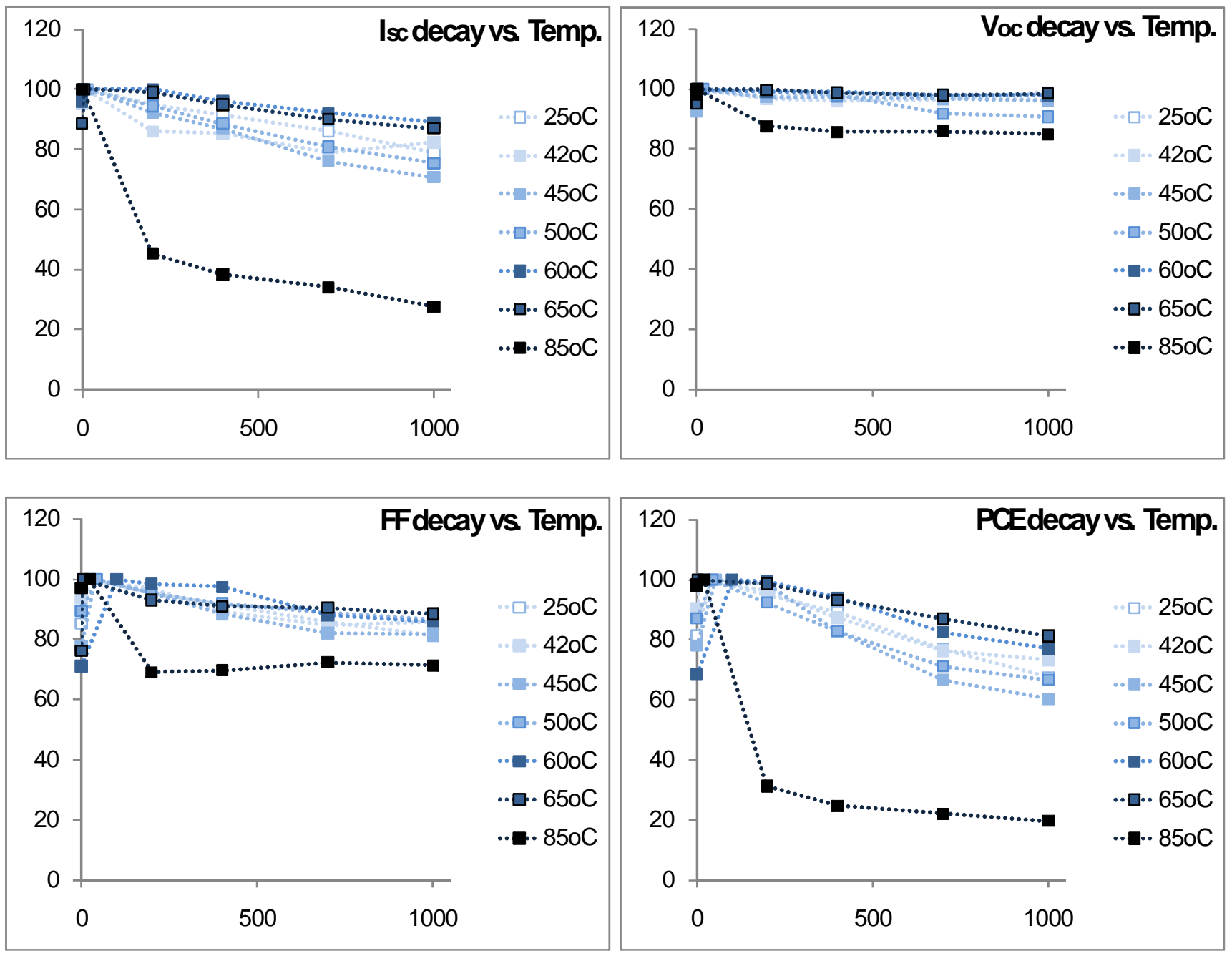

Figure 8. Normalized values of pv parameters vs time (hrs) at different Temp. in the range of $25-85{ }^{\circ} \mathrm{C}$. The $\mathrm{RH}$ range was $20-25 \%$. The measurement points are connected by dashed lines for guiding the eye.

Conclusions for T1B: The following can be concluded from the experiments:

- For these particular devices the temperature variations seemed to have a small affect, while RH variations resulted in a large spread of data. Therefore, careful 
control of RH levels during testing of such modules can lead to a more accurate stability testing and reproducible data.

- The groups perform stability studies using a rather large diversity of temp./RH combinations, which makes it impractical to compare the module performance across laboratories. Thus, certain standards have to be defined, such that 2 or 3 combinations of Temp./RH than can be agreed upon and followed by all the groups in OPV community. The temperature and especially RH level will need to be carefully controlled to obtain accurate data.

\subsubsection{Light Soaking Test (T2)}

The purpose of $\mathrm{T} 2$ test was to establish the capability of different groups of carrying out light soaking tests and to check the reproducibility of the results across different laboratories.

Results: Table 14 shows the list of 14 laboratories that carried out the T2 test on a total of 21 ST type modules and 22 of the 3 other types of modules. The table includes also the light sources that have been used during the tests. Due to rather scarce data and large deviations among different reports the approach used for processing T1A data would not be very informative in this case. The standard deviations for most of the parameters at all time points were above $20 \%$. Therefore, we chose to show the original data instead. Figure 9 shows all the curves for 14 ST modules (data for 7 modules were unreadable) with colors defining the types of the lamps used for light soaking. 3 types of light sources were used, categorized as 
Halogen Lamps (2 modules), Metal Halide Lamps (5 modules) and Sulfur Plasma Lamps (7 modules). Most of the tests were carried out at light intensities close to 1 sun and for the examples that significantly deviated from 1 sun, the time axes were adjusted in the plots, so that at a given time all the modules received approximately the same dose of energy. Although this correlation is not entirely fair due to differences in temperatures and other environmental parameters, it at least excludes the light intensity variations. For comparison the black solid line shows the average of modules tested under real sun under outdoor conditions (the time is adjusted to have a similar energy dose). It is easy to see how large the diversity of the degradation kinetics for the modules is when measured in different laboratories. In most cases the temperature and $\mathrm{RH}$ were not recorded/reported and in the cases where the $\mathrm{RH}$ was reported the values were used to check if there was a correlation between the data spread and temperature/RH variations. No such correlations were found. The modules behaved entirely random with respect to both temperature and RH.

Table 14. The list of the laboratories for $T 2$ experiment. The starting date of experiment, the types of light sources and intensities and the ranges of temperature and RH are shown as well.

\begin{tabular}{|c|c|c|c|c|c|c|c|}
\hline $\begin{array}{l}\text { Package } \\
\text { number }\end{array}$ & Laboratory & $\begin{array}{l}\text { Starting } \\
\text { Date }\end{array}$ & $\begin{array}{c}\text { Sampl } \\
\text { e } \\
\text { quanti } \\
\text { ty }\end{array}$ & Light Source & $\begin{array}{c}\text { Intensit } \\
\mathrm{y} \\
\left(\mathrm{W} / \mathrm{m}^{2}\right)\end{array}$ & $\begin{array}{l}\text { Storage } \\
\text { Temp. }\end{array}$ & $\begin{array}{l}\text { Storage } \\
\text { R.H. (\%) }\end{array}$ \\
\hline 9 & $\begin{array}{c}\text { Hermenau, M. } \\
\text { (IAPP) }\end{array}$ & $31 / 05$ & 1 & $\begin{array}{c}\text { Halogen Lamp } \\
\text { (Without UV) }\end{array}$ & 1000 & 40 & - \\
\hline 10 & $\begin{array}{c}\text { Hoppe, H. (TU } \\
\text { Ilmenau) }\end{array}$ & $28 / 05$ & 1 & Metal Halide Lamp & 1000 & - & - \\
\hline$* 11$ & $\begin{array}{l}\text { Lloyd, M. } \\
\text { (NREL) }\end{array}$ & $11 / 06$ & 2 & $\begin{array}{c}\text { UV soak (300-400 } \\
n \mathrm{~m})\end{array}$ & 114 & 60 & 60 \\
\hline$* * 12$ & $\begin{array}{c}\text { Xiao, M. } \\
\text { (Plextronics) }\end{array}$ & $28 / 05$ & 5 & Q-Sun & $\sim 500$ & 60 & 70 \\
\hline 14 & Rath, T. (TU & $31 / 05$ & 5 & LG PSH0731WA & 500 & - & - \\
\hline
\end{tabular}




\begin{tabular}{|c|c|c|c|c|c|c|c|}
\hline & Graz) & & & sulfur plasma lamp & & & \\
\hline 16 & $\begin{array}{l}\text { Watkins, S. } \\
\text { (CSIRO, } \\
\text { Melbourne) }\end{array}$ & $01 / 06$ & 1 & $\begin{array}{c}\text { Newport-Oriel Solar } \\
\text { Simulator }\end{array}$ & 1000 & 38 & 28 \\
\hline 16 & $\begin{array}{l}\text { Watkins, S. } \\
\text { (CSIRO, } \\
\text { Newcastle) }\end{array}$ & $01 / 06$ & 1 & Metal Halide Lamp & 460 & 40 & $15-30$ \\
\hline 17 & $\begin{array}{c}\text { Zimmerman, B. } \\
\text { (ISE) }\end{array}$ & $31 / 05$ & 5 & Sulfur Plasma Lamp & 1000 & 50 & - \\
\hline 18 & Kim, K. (KIST) & $30 / 05$ & 4 & $\begin{array}{l}\text { Metal Halide Lamp } \\
\text { (Xe Arc Lamp) }\end{array}$ & 900 & 35 & - \\
\hline 21 & $\begin{array}{l}\text { Schwartz, G. } \\
\text { (Heliatek) }\end{array}$ & - & 2 & Sulfur Plasma Lamp & 1064 & 50 & $<10$ \\
\hline$* * 22$ & $\begin{array}{l}\text { Elschner, A. } \\
\text { (H.C. Starck) }\end{array}$ & $28 / 05$ & 5 & Atlas XLS+ & 600 & 22 & - \\
\hline 23 & $\begin{array}{c}\text { Veenstra, S.C. } \\
\text { (ECN) }\end{array}$ & - & 5 & Sulfur Lamp & 1000 & $45-47$ & - \\
\hline$* * * 25$ & $\begin{array}{l}\text { Hauch, J. } \\
\text { (Konarka) }\end{array}$ & - & 2 & - & 1000 & - & - \\
\hline 26 & Ris $\varnothing$ DTU & $31 / 05$ & 4 & $\begin{array}{c}\text { Steuernagel Solar } \\
\text { Constant } 1200\end{array}$ & 1000 & 65 & 15 \\
\hline
\end{tabular}

*2-3 measurements were performed during the decay

**Illumination of samples was not continuous, but periodic

***Measurements were carried out until $250 \mathrm{hrs}$

One common feature that can be seen in the plots is that modules tested using sulfur plasma lamps (red circles) seemed to be more stable. It perhaps can be explained by the fact that the UV content in these lamps is usually less compared to metal halide lamps. Although the samples need some initial UV photo-doping to recover from inflection point, the long term UV irradiation can be disadvantageous for stability. 

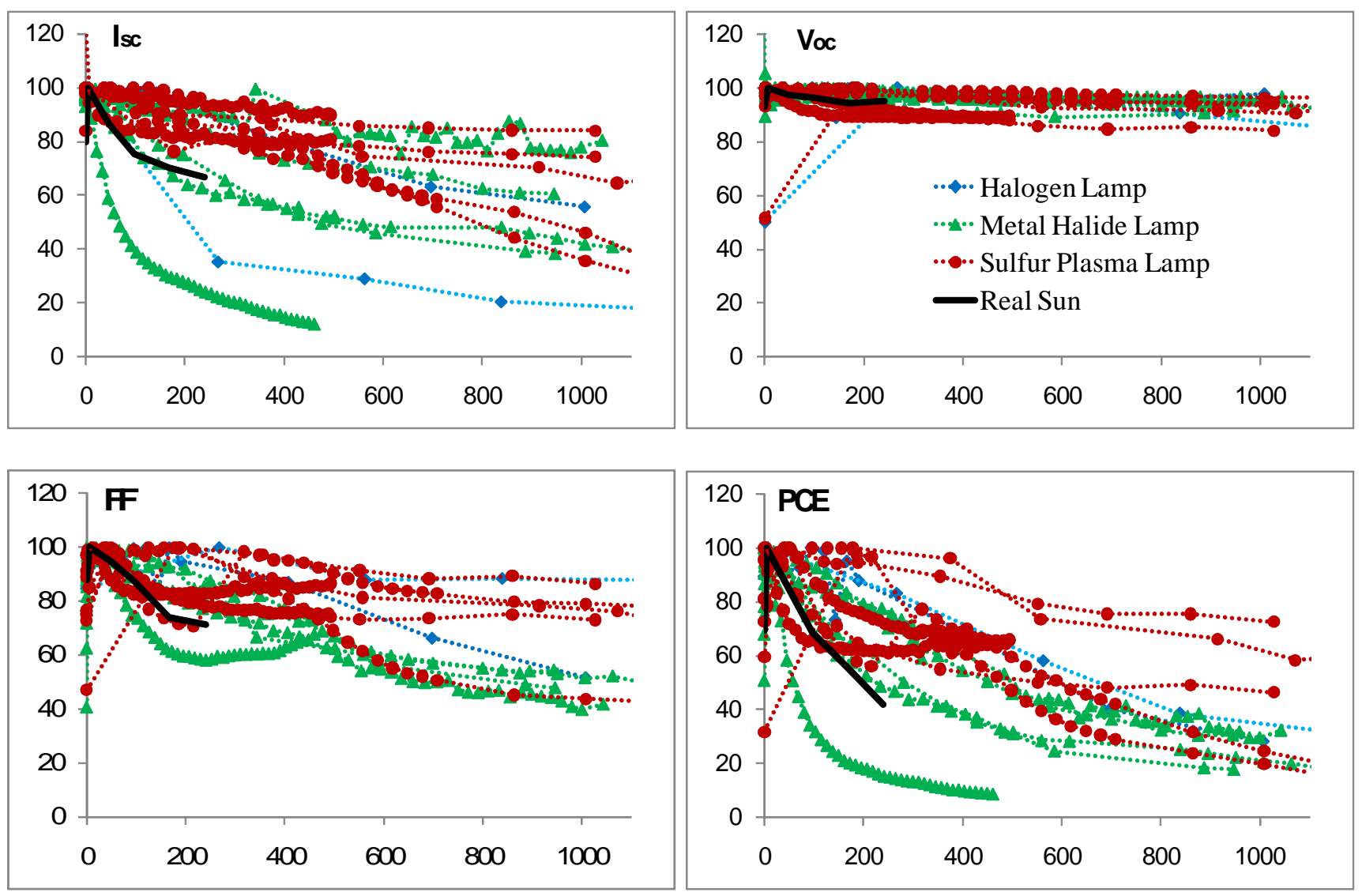

Figure 9. Decay of pv parameters for 14 modules measured in different labs. Red circles correspond to sulfur plasma lamps, green triangles to metal halide lamps and blue rhombs to halogen lamps. The measured points are connected by dashed lines for guiding the eye.

3 groups had 2 modules tested under the same conditions. Table 15 shows the calculated averages of the intra-laboratory and inter-laboratory average deviations for 3 groups, which show that up to $60 \%$ of deviations can easily be attributed to the intrinsic differences of decay kinetics between the modules. The processing of three other types of modules (MN, PN and RN) led to similar results as for ST. The plots can be found in the supporting information. 
Table 15. Intra-lab and Inter-lab SD values averaged for 4 time points and their ratio in percent.

\begin{tabular}{|c|c|c|c|c|}
\hline SD & $\mathrm{I}_{\mathrm{sc}}$ & $\mathrm{V}_{\mathrm{oc}}$ & $\mathrm{FF}$ & PCE \\
\hline Inter-Laboratory & 12.4 & 4.3 & 12 & 17 \\
\hline Intra-Laboratory & 4.4 & 2.3 & 6 & 9 \\
\hline Ratio & $47 \%$ & $53 \%$ & $50 \%$ & $57 \%$ \\
\hline
\end{tabular}

Conclusions: The results of the $\mathrm{T} 2$ experiments suggest that the conditions used for light soaking studies significantly vary across the laboratories. In particular, the spectrum of the light sources, light intensities, device temperatures and RH levels are different in different laboratories, which result in a large spread of degradation data when compared among laboratories. Based on these studies, a number of conditions are proposed here for carrying out light soaking tests, which can possibly lead to more accurate measurements and perhaps improve the compatibility of the reports among groups:

- A certain type of light source or light filters need to be defined and used among groups that will assure a similar spectral distribution of the light that the devices are being exposed to. It will thus exclude the variations caused by spectral differences

- The light intensity needs to be kept at around $1000 \mathrm{~W} \mathrm{~m}^{-2}( \pm 5 \%)$. In this way the modules will receive an equal amount of energy dose at a given time.

- Similar to the previous section a certain combination of temperature/RH have to be defined and the modules have to be kept under these conditions $( \pm 5)$ to avoid any further scattering due to these environmental factors 


\subsubsection{Outdoor Testing (T3A\&B)}

Two types of outdoor experiments were explored. In one the modules were being stored outdoors at all times and measured in the same position under real sun (T3A) and in the other one the cells were being stored outdoors and taken inside periodically (daily or weekly) and measured under calibrated sun simulator (T3B). There were two reasons to split outdoor test to A and B: firstly, in order to meet capabilities of wider range of laboratories and secondly, it would allow for a comparison of the two approaches and establishing the weak spots for each one. Six groups reported studied devices according to the T3A type with a total of 25 modules (16 of the ST type and 9 of the other types) and 15 chose to follow the T3B approach with a total of 29 modules ( 23 of the ST type and 6 of the other types). Table 16 and 17 show the lists of the groups that correspondingly chose T3A and T3B. The tables include the type of the outdoor platform used for studies. A number of photographs are presented in figure 10, which show the variability of the conditions that the modules were exposed to. In particular, figure 10 (7) shows the result of a storm in Australia during studies. The photo is taken 100 meters away from the testing platform.

Table 16. The list of the laboratories for T1A experiment. The starting date of experiment, the outdoor platform and the angle of exposure are listed as well.

\begin{tabular}{|c|c|c|c|c|c|}
\hline $\begin{array}{c}\text { Package } \\
\text { number }\end{array}$ & Laboratory & $\begin{array}{c}\text { Starting } \\
\text { Date }\end{array}$ & $\begin{array}{c}\text { Sample } \\
\text { quantity }\end{array}$ & Outdoor Platform & $\begin{array}{c}\text { Exposur } \\
\text { e Angle }\end{array}$ \\
\hline 1 & Riede, M. (Stanford) & $18 / 06$ & 8 & Stand Still & $0^{\circ}$ \\
\hline 2 & Katz, E. (BGU) & $07 / 06$ & 8 & $\begin{array}{c}\text { Stand Still Facing } \\
\text { South }\end{array}$ & $30^{\circ}$ \\
\hline 10 & Hoppe, H. (TU Ilmenau) & $28 / 05$ & 2 & $\begin{array}{c}\text { Stand Still Facing } \\
\text { South }\end{array}$ & $45^{\circ}$ \\
\hline
\end{tabular}




\begin{tabular}{|c|c|c|c|c|c|}
\hline 16 & $\begin{array}{c}\text { Watkins, S. (CSIRO, } \\
\text { Melbourne) }\end{array}$ & $02 / 06$ & 1 & $\begin{array}{c}\text { Stand Still Facing } \\
\text { North }\end{array}$ & $37^{\circ}$ \\
\hline 16 & $\begin{array}{c}\text { Watkins, S. (CSIRO, } \\
\text { Newcastle) }\end{array}$ & $01 / 06$ & 4 & $\begin{array}{c}\text { Stand Still Facing } \\
\text { North }\end{array}$ & $32^{\circ}$ \\
\hline 22 & Elschner, A. (H.C. Starck) & $07 / 06$ & 2 & $\begin{array}{c}\text { Stand Still Facing } \\
\text { South }\end{array}$ & $10^{\circ}$ \\
\hline
\end{tabular}

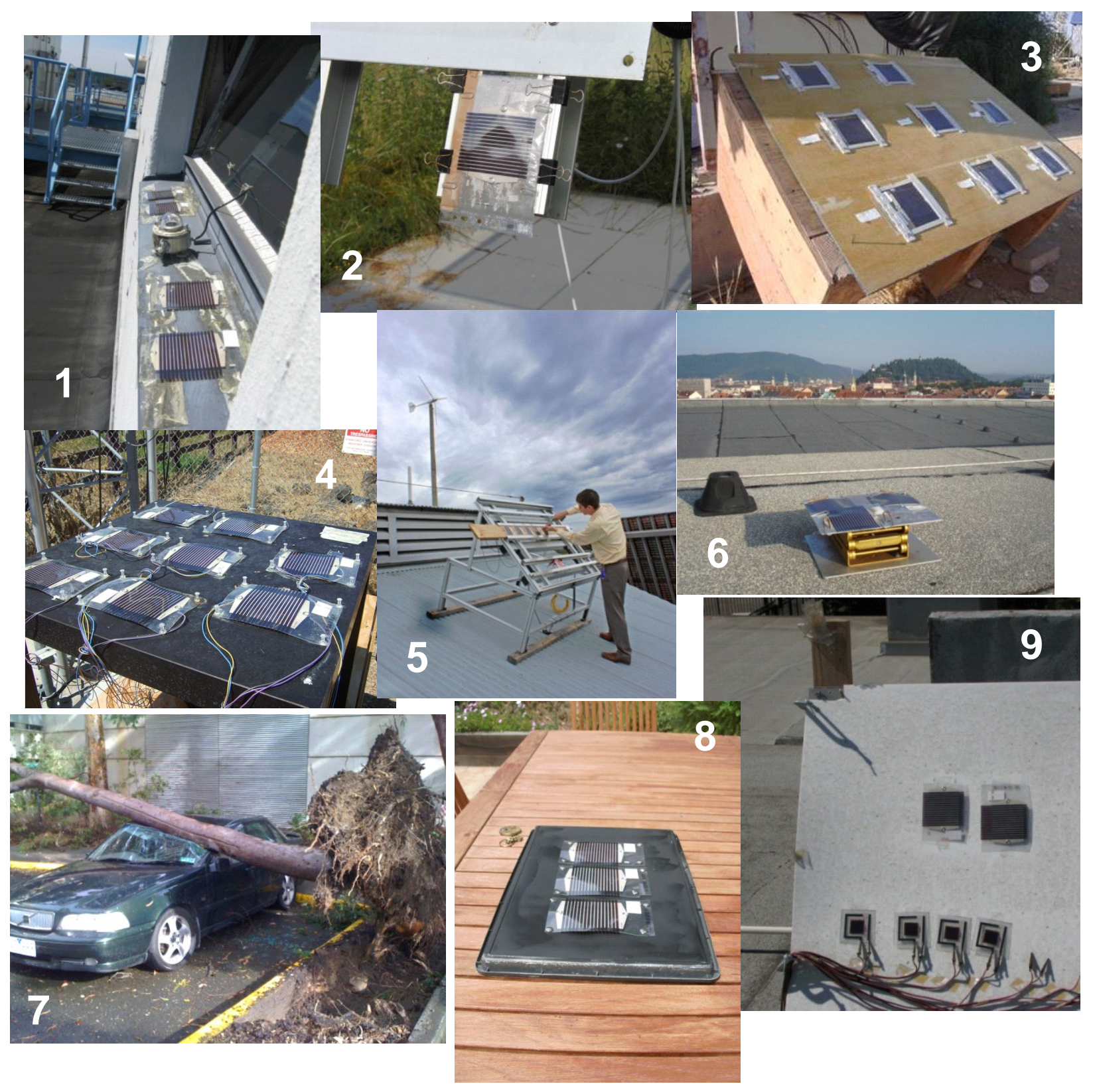


Figure 10. (1) HC Starck, rooftop platform: modules facing south at $10^{\circ}$ (Germany); Risø DTU, module mounted on the solar tracker (Denmark); (3) Stand still platform: modules facing south at 30 (BGU, Israel); (4) Horizontally oriented table platform (Stanford, USA); (5) CSIRO, rooftop platform: modules facing north at $32^{\circ}$ (Newcastle, Australia); (6) TU Graz, rooftop platform (Austria) (7) Results of a storm: photo taken 100 meters away from the testing platform (Melbourne, Australia); (8) Stand still plate: modules facing south at $\sim 10^{\circ}$ (Barcelona, Spain) (9) Rooftop testing station: modules facing south at $28^{\circ}$ (Solarmer, USA).

Table 17. The list of the laboratories for T1B experiment. The starting date of experiment, the outdoor platform and the angle of exposure are listed as well.

\begin{tabular}{|c|c|c|c|c|c|}
\hline $\begin{array}{l}\text { Package } \\
\text { number }\end{array}$ & Laboratory & $\begin{array}{l}\text { Starting } \\
\text { Date }\end{array}$ & $\begin{array}{l}\text { Sample } \\
\text { quantity }\end{array}$ & Outdoor Platform & $\begin{array}{c}\text { Exposure } \\
\text { Angle }\end{array}$ \\
\hline 5 & $\begin{array}{c}\text { Galagan, Y.O. (Holst } \\
\text { Center) }\end{array}$ & - & 1 & - & - \\
\hline 6 & $\begin{array}{l}\text { Shrotriya, V. } \\
\text { (Solarmer) }\end{array}$ & $01 / 06$ & 2 & $\begin{array}{l}\text { Stand Still Facing } \\
\text { South }\end{array}$ & $28^{\circ}$ \\
\hline 7 & $\begin{array}{l}\text { Lira-Cantu, M. (CIN2, } \\
\text { CSIC) }\end{array}$ & $29 / 05$ & 3 & $\begin{array}{c}\text { Stand Still Facing } \\
\text { South }\end{array}$ & $8^{\circ}-12^{\circ}$ \\
\hline 10 & $\begin{array}{l}\text { Hoppe, H. (TU } \\
\text { Ilmenau) }\end{array}$ & $28 / 05$ & 4 & $\begin{array}{l}\text { Stand Still Facing } \\
\text { South }\end{array}$ & $45^{\circ}$ \\
\hline$* 13,24$ & Haillant, O. (ATLAS) & - & 26 & - & - \\
\hline 14 & Rath, T. (TU Graz) & $31 / 05$ & 3 & Stand Still & $0^{\circ}$ \\
\hline 16 & $\begin{array}{l}\text { Watkins, S. (CSIRO, } \\
\text { Melbourne) }\end{array}$ & $01 / 06$ & 1 & $\begin{array}{l}\text { Stand Still Facing } \\
\text { North }\end{array}$ & $37^{\circ}$ \\
\hline 16 & $\begin{array}{c}\text { Watkins, S. (CSIRO, } \\
\text { Newcastle) }\end{array}$ & $01 / 06$ & 1 & $\begin{array}{c}\text { Stand Still Facing } \\
\text { North }\end{array}$ & $32^{\circ}$ \\
\hline 17 & Zimmerman, B. (ISE) & $31 / 05$ & 5 & - & - \\
\hline 18 & Kim, K. (KIST) & $30 / 05$ & 1 & - & - \\
\hline 19 & Swonke, T (ZAE) & $31 / 05$ & 2 & Stand Still & $45^{\circ}$ \\
\hline 21 & Schwartz, G. (Heliatek) & - & 1 & - & - \\
\hline 22 & $\begin{array}{c}\text { Elschner, A. (H.C. } \\
\text { Starck) }\end{array}$ & $01 / 06$ & 2 & $\begin{array}{l}\text { Stand Still Facing } \\
\text { South }\end{array}$ & $10^{\circ}$ \\
\hline 23 & Veenstra, S.C. (ECN) & - & 2 & $\begin{array}{l}\text { Stand Still Facing } \\
\text { South }\end{array}$ & $30^{\circ}$ \\
\hline 26 & Ris $\varnothing$ DTU & $31 / 05$ & 1 & Solar tracker & - \\
\hline
\end{tabular}

*Details of studies at ATLAS are described in section 3.6.3

\subsubsection{1 $\underline{\mathrm{T} 3 \mathrm{~A}}$}

Outdoor Fluctuations: In T3A experiment the devices were left outside during the entire study (day and night) and periodically measured under real sun. The groups 
mainly used stationary platforms at certain angles mostly adjusted to the latitude of the location and only at Risø DTU a solar tracker was employed. The amounts of energy doses significantly varied across the laboratories due to various angles used and due to different weather conditions. The results were not normalized with respect to the energy doses due to unavailable data in most cases, which contributed to the spread of data. Normally, the sun intensity was recorded using a pyranometer placed next to the cells and the intensity was recorded during the IV-curve measurement of the module. The measured $\mathrm{I}_{\mathrm{sc}}$ was normalized to $1000 \mathrm{~W} \mathrm{~m}^{-2} \mathrm{using}$ the linear fit. Only values within the range of 800 to $1100 \mathrm{~W} \mathrm{~m}^{-2}$ were considered. However, often there was a delay between the recording of sun intensity and the $I_{s c}$ as shown in figure 11(a), which caused some miscalculations of the current (the delay was not constant along the degradation process).

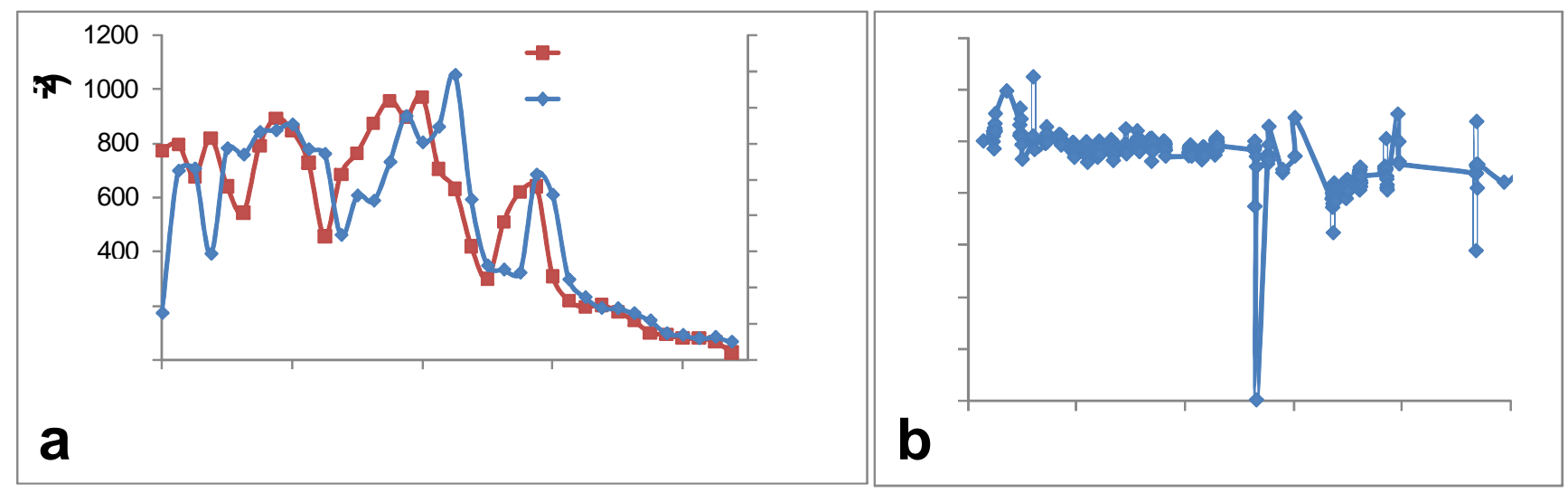

Figure 11. (a) delay between recording of light intensity and $I_{s c}$ and (b) fluctuations of $I_{s c}$ possibly caused by shadowing, winds and week contacts.

In addition, some fluctuations of the recorded current were observed even after normalizing the values to $1000 \mathrm{~W} \mathrm{~m}^{-2}$, such as for example shown in Figure 11(b). 
The reason is ascribed to the sudden shadowing of the radiation by clouds during the measurements, which were not recorded by pyranometer. Strong winds could cause flipping of the cells, or loosening of the contact, which was a source of additional fluctuations. In some cases, shadowing of the sunlight by the surrounding trees in early mornings or late afternoons have been reported as well. If for example the pyranometer was placed at a certain distance from the cells, it is possible that the shadowing of the cell by the trees would not be recorded by the pyranometer, which could result in a wrong estimation of $I_{s c}$. Bird droppings and dust are additional factors contributing to performance variations. All the aforementioned factors can greatly contribute to data spread.

Results of Measurements: The data were processed and presented in similar manner as for T1A studies. Figure 12 shows the results of T3A measurements on 16 ST type modules by total of 6 groups. Table 18 shows the average values and SDs calculated for 5 time points. Deviations in this case are somewhat larger (up to nearly 15\%) compared to shelf life studies, but the difference is not significant considering all the aforementioned fluctuations. It can be explained by two reasons: 1 . The frequency of measurements in this study was quite high (in the range of $15 \mathrm{~min}$ to few hrs) and therefore, the determination of maximum values was rather accurate; 2. The modules remained on the platforms at all times and the mechanical stresses due to handling were thus minimal. 

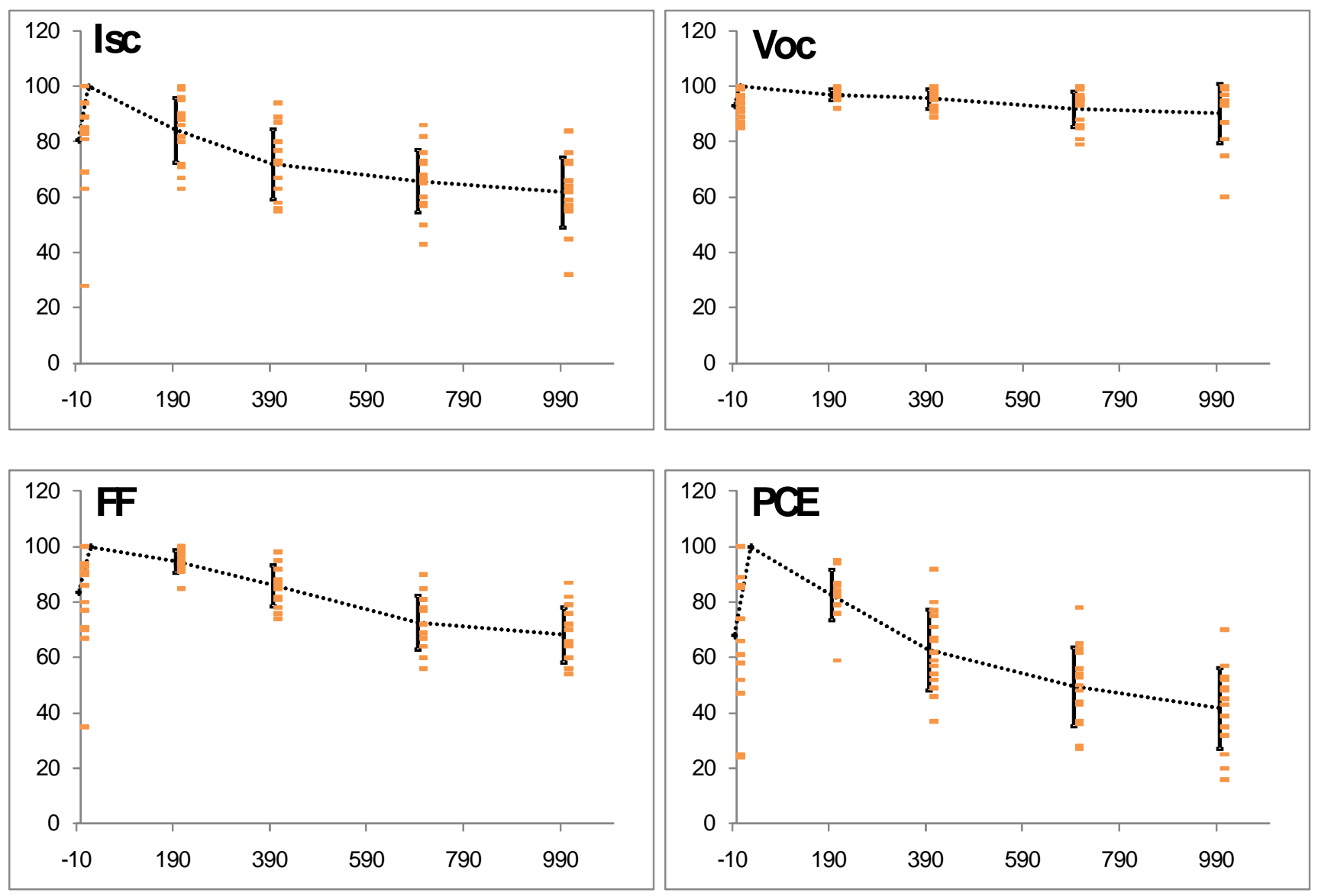

Figure 12. Variation of pv parameters across the time measured on 16 modules (orange rectangles). The parameters are normalized to maximal values. Horizontal axes represent the time (hrs). The dashed line intersects the average values and the error bars represent the SDs.

Table 18. The average of pv parameters at different times and the corresponding SDs.

\begin{tabular}{|c|c|c|c|c|c|c|c|c|}
\hline \multirow{2}{*}{ Time (hrs) } & \multicolumn{2}{|c|}{$\mathrm{I}_{\mathrm{sc}}$ (Normalized) } & \multicolumn{2}{c|}{$\mathrm{V}_{\text {oc }}$ (Normalized) } & \multicolumn{2}{c|}{ FF (Normalized) } & \multicolumn{2}{c|}{ PCE(Normalized) } \\
\cline { 2 - 9 } & Average & SD & Average & SD & Average & SD & Average & SD \\
\hline $\mathrm{t}_{\max }$ & 100 & - & 100 & - & 100 & - & 100 & - \\
\hline 200 & 84 & 11.6 & 97 & 2 & 95 & 3.9 & 83 & 9 \\
\hline 400 & 72 & 12.7 & 96 & 3.4 & 86 & 7.4 & 63 & 14.6 \\
\hline 700 & 66 & 11.4 & 92 & 6.5 & 73 & 9.7 & 50 & 14.3 \\
\hline 1000 & 62 & 12.7 & 90 & 10.8 & 68 & 9.9 & 42 & 14.5 \\
\hline
\end{tabular}


Intra-laboratory and Inter-laboratory studies: In addition, Table 19 shows the values and the ratio of intra-laboratory and inter-laboratory SDs for 13 modules. The intra-laboratory variations are below $60 \%$ of the inter-laboratory variations for all the parameters.

Table 19. Intra-laboratory and Inter-laboratory SD values averaged for 4 time points and their ratio in percent.

\begin{tabular}{|c|c|c|c|c|}
\hline $\mathrm{SD}$ & $\mathrm{I}_{\mathrm{sc}}$ & $\mathrm{V}_{\mathrm{oc}}$ & $\mathrm{FF}$ & PCE \\
\hline Inter-Laboratory & 10.6 & 5.6 & 6.9 & 11.6 \\
\hline Intra-Laboratory & 4.4 & 3 & 3.7 & 4.7 \\
\hline Ratio & $42 \%$ & $56 \%$ & $58 \%$ & $42 \%$ \\
\hline
\end{tabular}

\section{Conclusions for T3A and Suggestions for Improvements:}

- Overall, the deviations of the data across labs are well below $15 \%$, which is rather low considering the large variations of the conditions among the laboratories. Such low numbers are attributed to the facts that the handling of devices in this experiment is minimal and the frequencies of the measurements are high allowing accurate determination of the lifetimes.

- One of the major factors contributing to the spread of data in this experiment is the difficulty of calculating the correct current due to uncertainty in the light intensity determination. Different energy doses across the laboratories are another factor of variability.

A number of steps can improve the accuracy of these measurements, such as: 
- The modules have to be placed away from any possible shadows

- The light intensity should be measured as frequently as possible and reported in order to accurately quantify the accumulative energy dose received by the module at any given time

- The measurements of light intensity and IV curves should be accurately correlated

- The measurements preformed while the intensity fluctuates by more than $10 \%$ within a period of 10 minutes should not be taken into account

\subsubsection{2 $\underline{\mathrm{T} 3 \mathrm{~B}}$}

The difference of T3B from T3A was that the cells were stored outside, but the measurements were carried out inside under a calibrated light sources. It excluded the factor of fluctuations and miscalculations of sun irradiation intensity. Yet, it added the factor of periodic handling (periodic dismounting from and mounting on the outdoor platform after indoor characterization) of the modules and thus increased the mechanical stresses on the modules. Furthermore, the measurements were obviously less frequent in this case (1/day to $1 /$ week). T3B also requires more workload for the experimenter to carry out these measurements compared to T3A.

Results of Measurements: 15 Laboratories carried out T3B type experiments on 23 ST type modules and 6 of 3 other type modules. Figure 13 shows the raw data for $I_{\text {sc }}$ for 23 ST type modules. 5 curves out of 23 marked with red circles in the figure have a 
catastrophic failure, which is attributed to the handling of the devices. If these 5 curves are excluded then the general results for T3B will appear as in Figure 14.

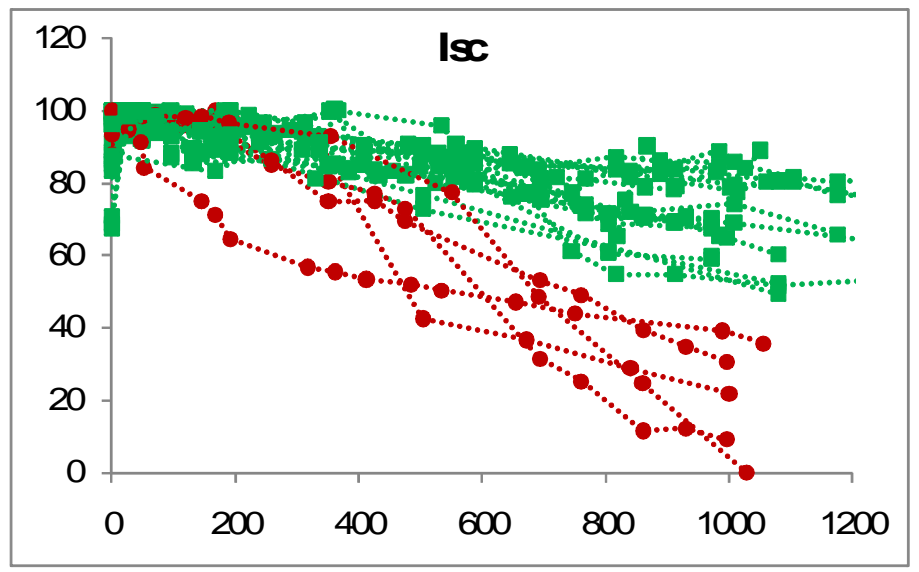

Figure 13. Raw data of $I_{s c}$ for 23 modules. The values are normalized to the maximum. Horizontal axis is the time (hrs). Red circles show the curves with catastrophic failures.

Table 20 shows the average and SD values for T3B without the outliers. The deviations are within approximately $16 \%$. If all the failed curves are added to the calculations then the spread of data will increase significantly reaching up to $26 \%$.

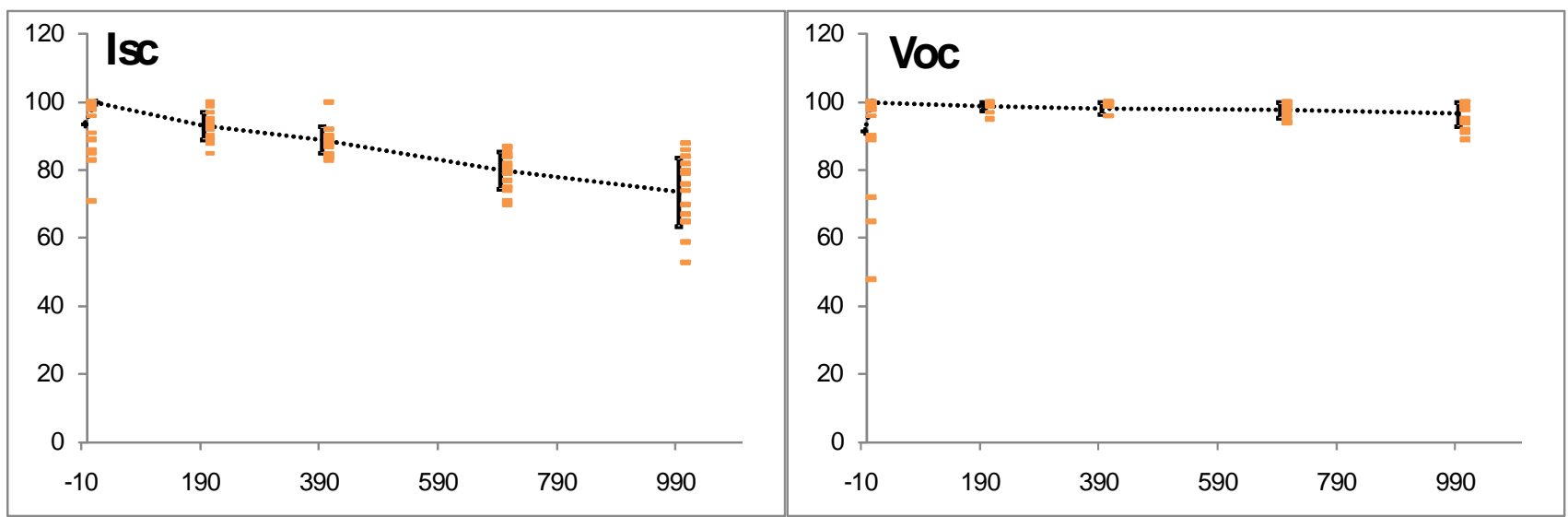




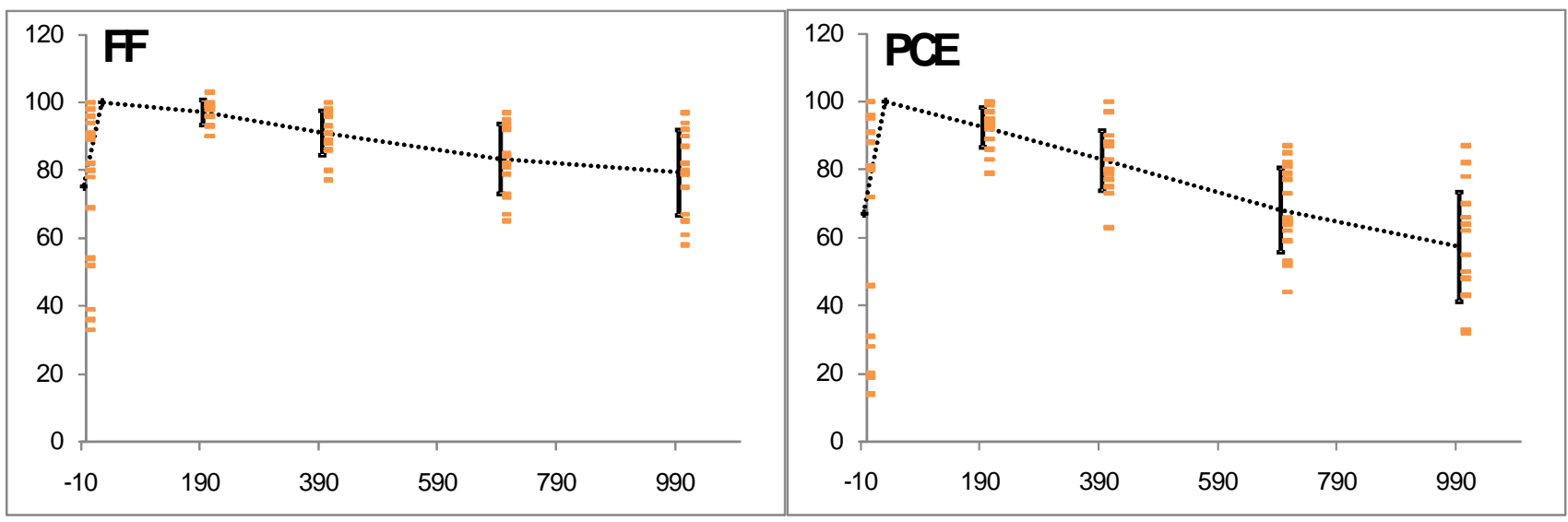

Figure 14. Variation of PV parameters across the time measured on 18 modules (orange rectangles). The parameters are normalized to maximal values. Horizontal axes represent the time (hrs). The dashed line intersects the average values and the error bars represent the SDs.

Table 21 shows the inter-laboratory and the intra-laboratory deviations. The numbers are again calculated excluding the failed curves. Except for $V_{\text {oc }}$, all other ratios between intra-laboratory and inter-laboratory SDs are below 40\%. The fact that both normal and failed curves have been recorded for modules measured in the same laboratory under same conditions further proves the hypothesis that the catastrophic failure of the curves is caused by handling and not by the storage conditions. The additional spread of data in this experiment comes from the fact that the measurements are less frequent and therefore the estimation of $t_{\max }$ is very approximate, which, as was mentioned earlier, can significantly contribute to the spread of SD values.

Table 20. The average of pv parameters at different times and the corresponding SDs. 


\begin{tabular}{|c|c|c|c|c|c|c|c|c|}
\hline \multirow{2}{*}{ Time (hrs) } & \multicolumn{2}{|c|}{$\mathrm{I}_{\mathrm{sc}}$ (Normalized) } & \multicolumn{2}{c|}{$\mathrm{V}_{\text {oc }}$ (Normalized) } & \multicolumn{2}{c|}{ FF (Normalized) } & \multicolumn{2}{c|}{ PCE (Normalized) } \\
\cline { 2 - 9 } & Average & SD & Average & SD & Average & SD & Average & SD \\
\hline $\mathrm{t}_{\max }$ & 100 & - & 100 & - & 100 & - & 100 & - \\
\hline 200 & 93 & 4.2 & 99 & 1.2 & 97 & 3.7 & 93 & 5.9 \\
\hline 400 & 89 & 4 & 98 & 1.7 & 91 & 6.6 & 83 & 8.9 \\
\hline 700 & 80 & 5.5 & 98 & 2.2 & 83 & 10.2 & 68 & 12.4 \\
\hline 1000 & 74 & 10 & 96 & 3.5 & 79 & 12.6 & 57 & 16.2 \\
\hline
\end{tabular}

Table 21. Intra-lab and Inter-lab SD values averaged for 4 time points and their ratio in percent.

\begin{tabular}{|c|c|c|c|c|}
\hline SD & $\mathrm{I}_{\text {sc }}$ & $\mathrm{V}_{\mathrm{oc}}$ & $\mathrm{FF}$ & PCE \\
\hline Inter-Laboratory & 6.6 & 1.7 & 8.7 & 10.3 \\
\hline Intra-Laboratory & 2.7 & 1.1 & 3.1 & 4.1 \\
\hline Ratio & $37 \%$ & $62 \%$ & $37 \%$ & $39 \%$ \\
\hline
\end{tabular}

Conclusions to T3B: To conclude T3B, a number of curves (22\% of total curves) had a catastrophic failure at some point, which was ascribed to the mechanical stresses cause by periodic handling of the cells. If the failed curves are excluded then the standard deviations for the photovoltaic parameters are within $16 \%$, which is mostly ascribed to the uncertainty of $t_{\max }$ due to scarce data and therefore, the inaccuracy in normalization of photovoltaic data.

\subsubsection{Standard Outdoor Testing at ATLAS}

ATLAS Material Testing Technology LLC carried out 3 types of outdoor testing according to ASTM international standards, such as Emmaqua, Desert Weathering and Inland Weathering. The Table in figure 15 shows the types and the details of each experiment and the photos illustrate the outdoor platforms used for testing. Unfortunately, a photo for inland weathering is not available. 

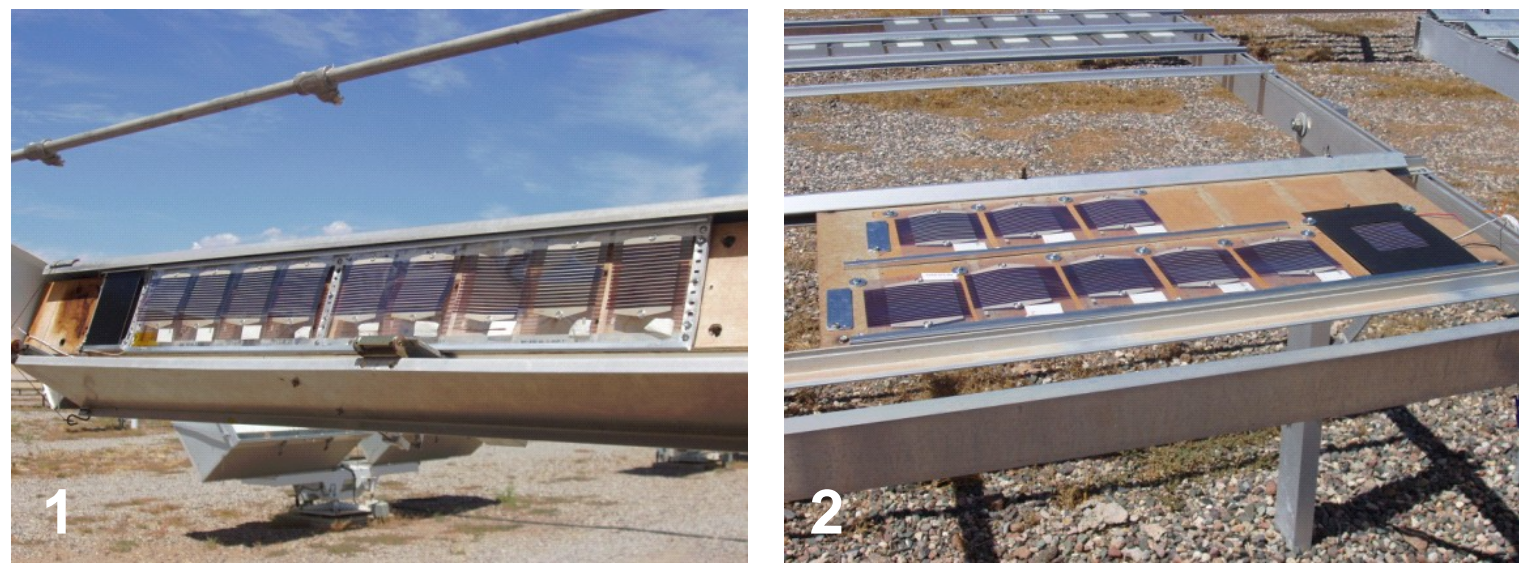

\begin{tabular}{|c|c|c|c|}
\hline Test Type & Emmaqua & Desert Weathering & Inland Weathering \\
\hline Test Location & New River, Arizona & New River, Arizona & Miami, Florida \\
\hline Number of Modules & 9 & 9 & 9 \\
\hline Standards & ASTM G147 - 2009 & $\begin{array}{l}\text { ASTM G24 - } 2005 \\
\text { ASTM G7 - } 2005\end{array}$ & $\begin{array}{l}\text { ASTM G147 - } 2009 \\
\text { ASTM G7 - } 2005\end{array}$ \\
\hline Exposure Type & $\begin{array}{l}\text { Exposure testing is } \\
\text { performed in } \\
\text { accordance with ASTM } \\
\text { G90, } \\
\text { SPRAY CYCLE } 1 \\
\text { (EMMAQUA, day spray } \\
\text { with night time } \\
\text { wetting). } \\
\text { Specimens are exposed } \\
\text { on a Temperature } \\
\text { Controlled EMMAQUA } \\
\text { with a temperature not } \\
\text { to exceed } 80^{\circ} \text { C }\end{array}$ & $\begin{array}{l}\text { Exposure testing is } \\
\text { performed in } \\
\text { accordance with } \\
\text { Governing } \\
\text { Standards at a tilt } \\
\text { angle(s) of } 5^{\circ} \text { from the } \\
\text { horizontal facing } \\
\text { south. }\end{array}$ & $\begin{array}{l}\text { Direct } 5^{\circ} \text { facing south, } \\
\text { plywood backing; } \\
\text { Energy dose: } \\
426 \mathrm{MJ} / \mathrm{m}^{2} \text { (Total); } \\
10,182 \mathrm{Langleys} \\
\mathrm{UV}: 26 \mathrm{MJ} / \mathrm{m}^{2}(295-385 \\
\mathrm{nm})\end{array}$ \\
\hline
\end{tabular}

Figure 15. The table outlining the details of 3 standard tests carried out by ATLAS and photos illustrating the outdoor platforms for Emmaqua (1) and Desert Weathering (2).

However, due to the relatively low amperage of the small modules studied here it was not possible to measure the IV curves at the recipient ATLAS laboratories. Thus, after different times of exposure the modules were shipped to Ris $\varnothing$ DTU and measu under calibrated light simulators to evaluate the decay level of each module at a certain time period. All the measured values were normalized to measurements performed at Ris $\varnothing$ DTU prior to shipping to ATLAS. Figure 16 shows the decay of each photovoltaic parameter after a certain time of exposure. One has to keep in 
mind, that each point in the plots corresponds to different modules and the plots should not be regarded as decay curves. However, the results give a good insight into how the modules behave at different conditions. The time axes only consider the exposure time and not the shipping time and storage in the dark.
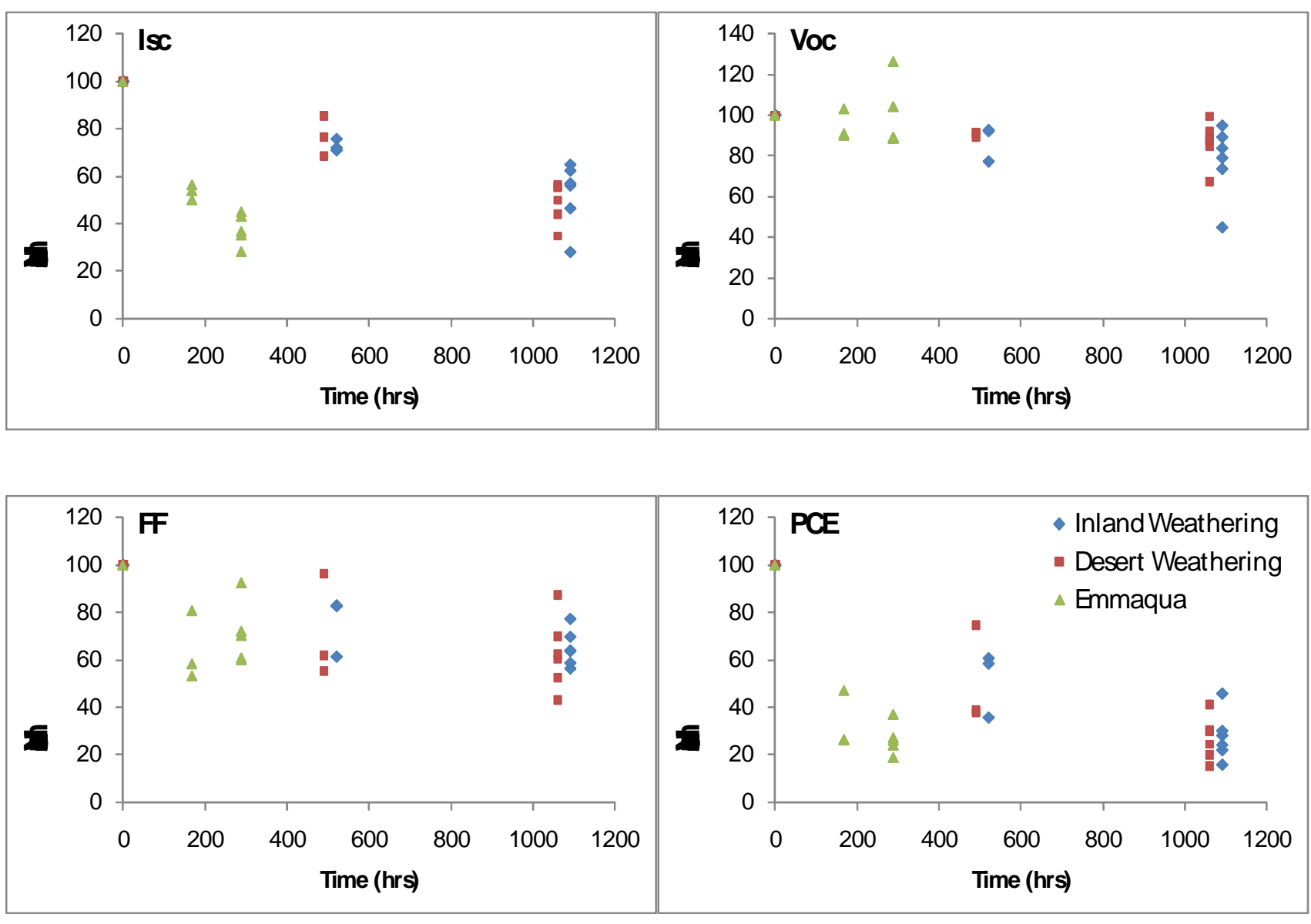

Figure 16. Decay of all pv parameters of the modules after certain time of exposure. Each point corresponds to different module.

Clearly Emmaqua, which involves periodically spraying the samples with water, is degrading the samples very fast compared to two other tests, while no difference can be seen between inland and desert experiments. No firm conclusions can be made 
however, since each module was measured only at one time point and different modules are compared along the time axes.

\subsubsection{Comparison of Different Tests}

Table 22 summarizes all the pros and cons for T1A, T2, T3A and T3B.

Table 22. Comparison of 4 different tests.

\begin{tabular}{|l|c|c|c|c|}
\hline Test & T1A & T2 & T3A & T3B \\
\hline Number of groups (modules) & $18(47)$ & $13(43)$ & $6(25)$ & $15(25)$ \\
\hline $\begin{array}{l}\text { Average of inter-lab (intra-lab) SDs } \\
\text { of Isc }\end{array}$ & $6.3(2.4)$ & $22(4.4)$ & $12(4.4)$ & $5.9(2.7)$ \\
\hline $\begin{array}{l}\text { Average of inter-lab (intra-lab) SDs } \\
\text { of Voc }\end{array}$ & $3.3(1.9)$ & $4.4(2.3)$ & $5.7(3)$ & $2.2(1.1)$ \\
\hline $\begin{array}{l}\text { Average of inter-lab (intra-lab) SDs } \\
\text { of FF }\end{array}$ & $6.2(3.5)$ & $13(6)$ & $7.7(3.7)$ & $8.3(3.1)$ \\
\hline $\begin{array}{l}\text { Average of inter-lab (intra-lab) SDs } \\
\text { of } \eta\end{array}$ & $8.5(4.4)$ & $19(8.9)$ & $13(4.7)$ & $11(4.1)$ \\
\hline Average T80 & $615 \mathrm{hrs}$ & $122 \mathrm{hrs}$ & $230 \mathrm{hrs}$ & $460 \mathrm{hrs}$ \\
\hline Frequency of measurements & Poor & Sufficient & Sufficient & Poor \\
\hline $\begin{array}{l}\text { Accuracy of Light Intensity during } \\
\text { measurements }\end{array}$ & $\begin{array}{c}\text { Sufficient (1 } \\
\text { sun) }\end{array}$ & $\begin{array}{c}\text { Sufficient (1 } \\
\text { sun) }\end{array}$ & $\begin{array}{c}\text { Poor } \\
\text { (fluctuating) }\end{array}$ & $\begin{array}{c}\text { Sufficient }(1 \\
\text { sun) }\end{array}$ \\
\hline Effect of ambient temp. and RH & Minimal & Significant & Major & Major \\
\hline Effect of periodic handling & Major & Minimal & Minimal & Major \\
\hline Effect of Light Spectrum & Minimal & Major & Minimal & Minimal \\
\hline
\end{tabular}

*The reason that $\mathrm{T} 3 \mathrm{~B}$ has in average longer lifetime is because in case of T3A modules measured at Sede Boqer were dying quickly due to rather high temperatures and thus significantly affect the average

\subsubsection{Results of additional studies}

\subsubsection{MPP versus Open Circuit}

The group from TU Graz tested the degradation of two identical devices under light soaking (T2), while one of them was kept at open circuit and the other at the maximum power point (MPP) using a Keithley 2400 SMU. Figure 17 shows the decay of the photovoltaic parameters for both modules. Although, there is a significant 
difference in the dynamics of the decay, overall the degradation of both devices is in the same range. However, since, only two modules were tested, it is hard to make any firm conclusions. Keeping the device at MPP during storage (active load) requires an expensive setup, which can be a hurdle for some groups. Thus, in order to compare stability among many groups, perhaps open circuit or a passive load (a resistor, which keeps the cell at MPP at the $\mathrm{t}_{0}$ point) should be suggested as a standard procedure, while active load can be used in advanced testing techniques.
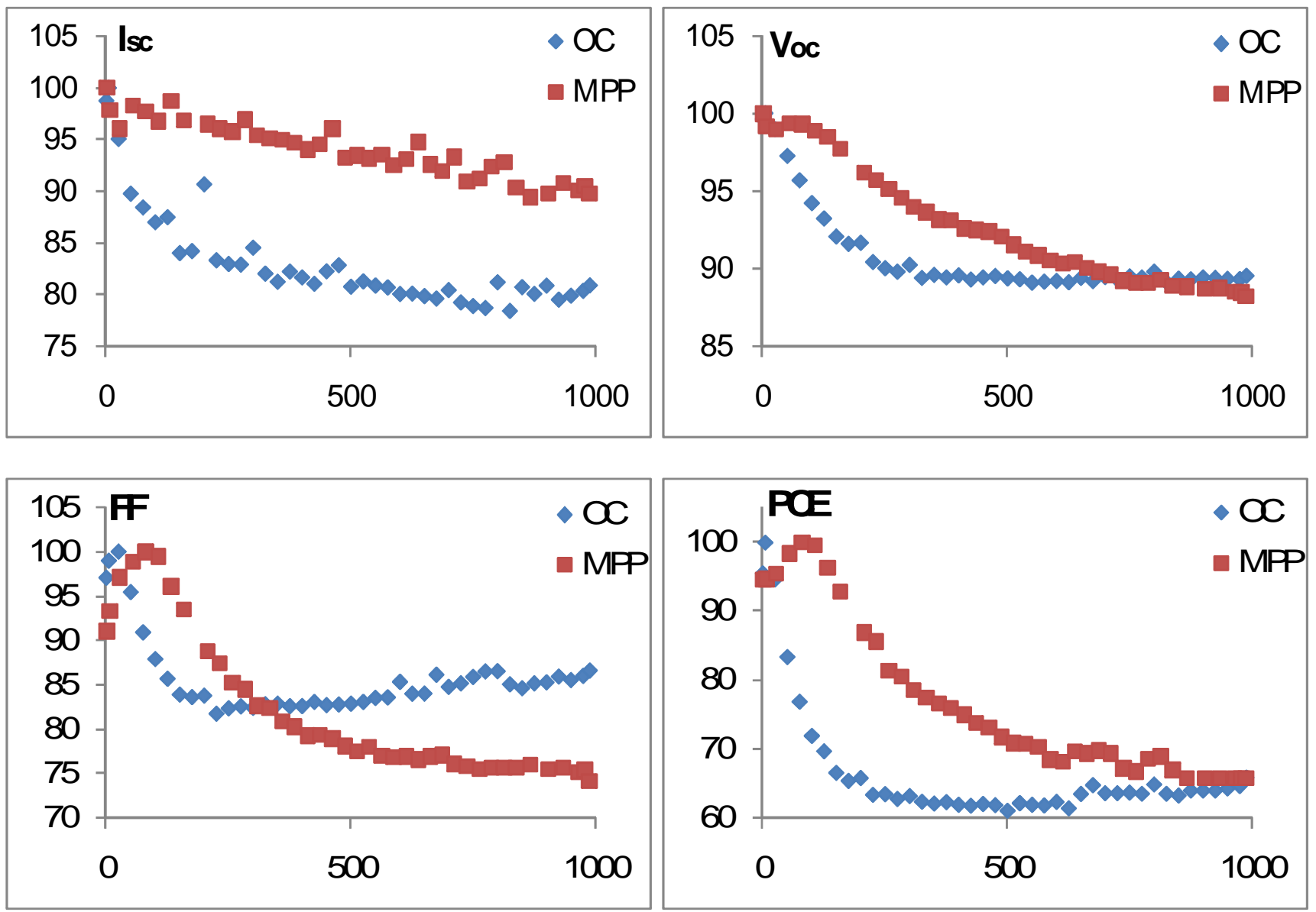

Figure 17. Light soaking testing of two identical modules one kept open circuited (blue rhombs) and other at mpp (red squares) carried out by the group from TU Graz. 


\subsubsection{Additional Protecting of the Sample}

The group from ECN showed how additional protection by a vacuum bag can affect the performance of devices during the outdoor exposure (T3B). Figure 18 shows PCE versus time for two identical modules one being protected additionally by a vacuum bag. The figure clearly shows a breaking of the module without additional protection at around $t_{400}$ probably due to handling, while the one with additional protection increases the performance during the timeline of the entire experiment. It is hard to make any conclusions, as only two modules were compared. However, the experiment confirms the fact that reducing the effect of environmental factors can considerably change the performance of the module.

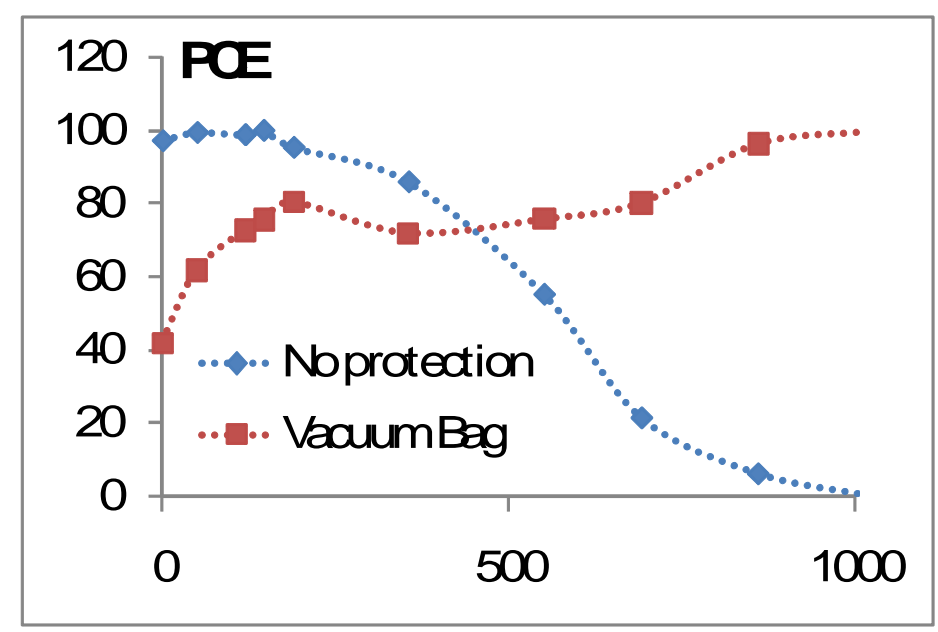

Figure 18. Outdoor testing two identical modules one being additionally protected by a vacuum bag. The measurements were carried out by the group from ECN. 


\subsubsection{Inflection Point Studies}

A number of groups worked on the reproducibility of the inflection point. In particular, the group from Israel observed a recovery of the FF after the device was kept in a dark for long time and then photo-annealed under real sun for short period. The group from Barcelona showed the recovery of PCE when the device (MN type) was kept in the dark and measured under light the first time and after a delay $(25 \mathrm{~min})$ the second time Figure 19(left). The recovery appears for all photovoltaic parameters $\left(I_{s c}, V_{o c}, F F\right.$ and PCE), but it is especially pronounced in FF. The group also showed the first increase and further degradation of IPCE for a ST type module kept in dark and measured under light source shown in Figure 19(right).
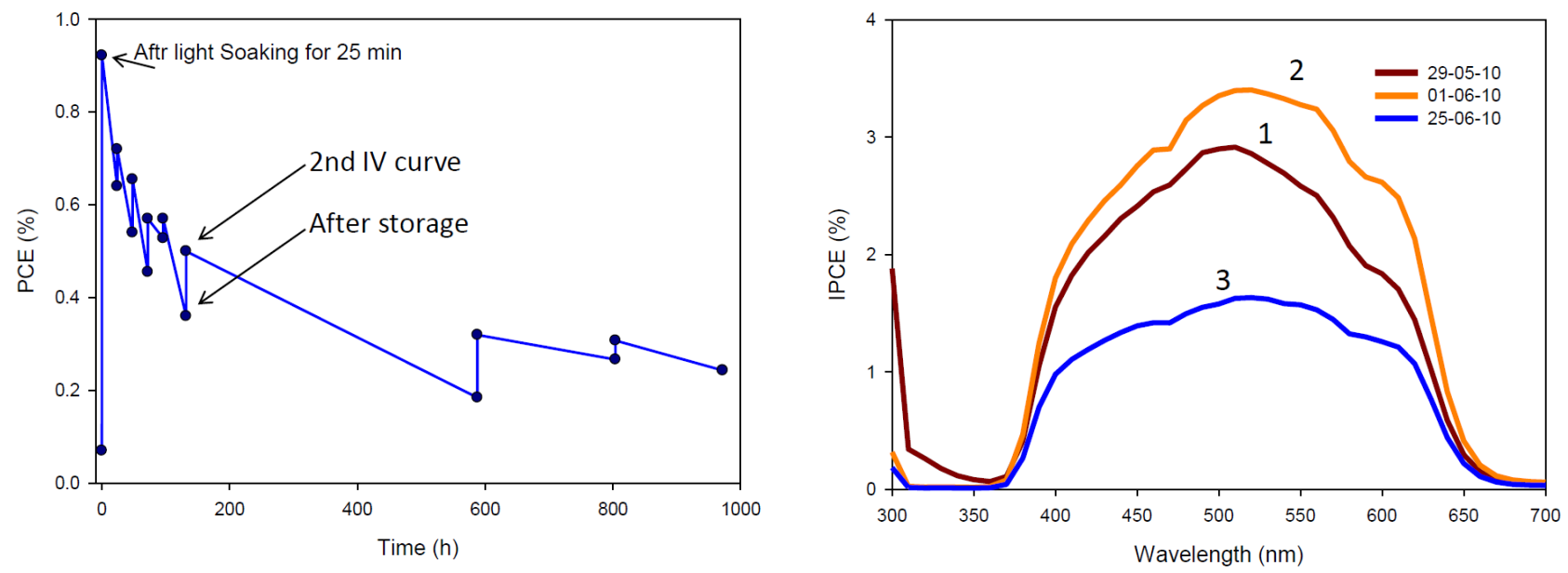

Figure 19. Recovery of $\eta$ after each photo-annealing due to the inflection point effect for MN type device (left) and the dynamics of IPCE change during decay studies for ST type module (right) reported by the group from CIN2, CSIC, Barcelona. 
Similarly results were reported by the group from Konarka Tech. Figure 20 (left) shows similar recovery nature of PCE, while Figure 20 (right) shows the dynamics of IV-curve change during the photo-annealing of the module.

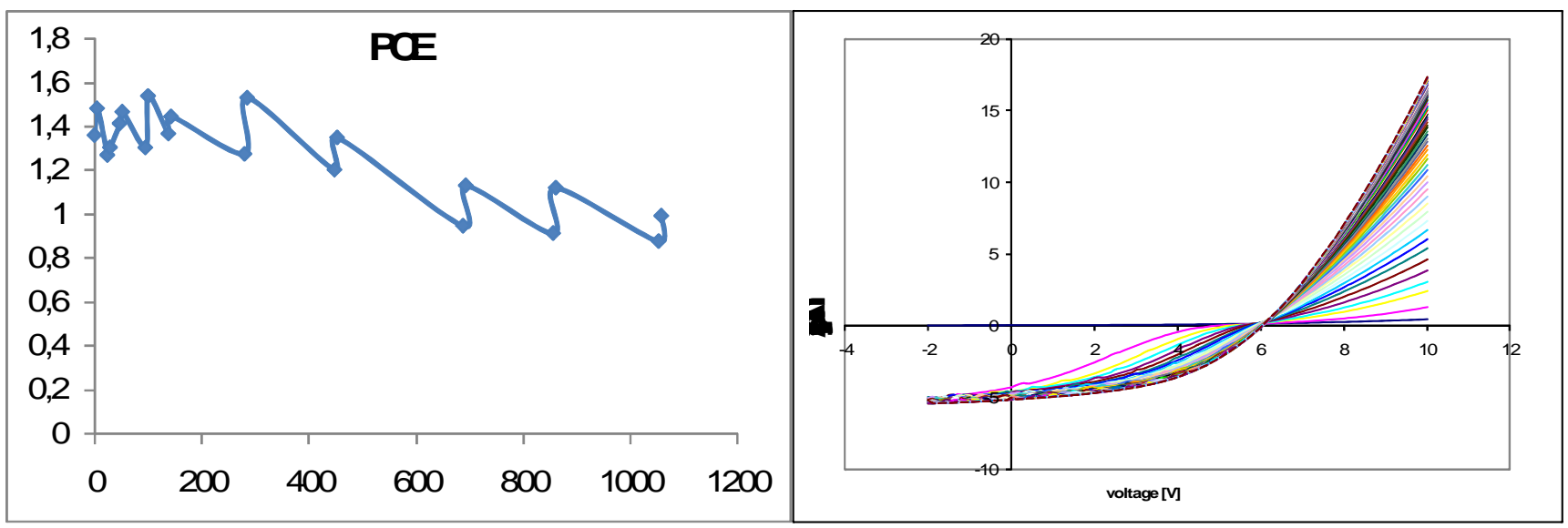

Figure 20. Recovery of $\eta$ after each photo-annealing due to the inflection point effect (left) and the dynamics of the IV-curve during photo-annealing of the device reported by Konarka Tech.

\subsubsection{Unreadable Data}

Some of the data were categorized as unreadable, since it was impossible to evaluate the degradation of the parameters. As an example, Figure 21 shows curves of Isc vs. time for two different modules. The lines are for guiding the eye. The reasons for such fluctuations are probably because the cells have been periodically exposed to different environments, such as, a drawer, light soaking and outdoor exposure.

Another factor that hampered the accurate estimation of degradation of parameters was the scarce data taken during the test. For example, 2 or 3 times measured devices during 1000 hrs cannot sufficiently give a picture of the decay. 5 points could more or less suffice, although determination of $\mathrm{t}_{\max }$ would involve large 
uncertainty and thus, contribute in the spread of general data. In addition, often measurements were carried out only during the first $100-200 \mathrm{hrs}$ and therefore, could not be estimated to $1000 \mathrm{hrs}$.
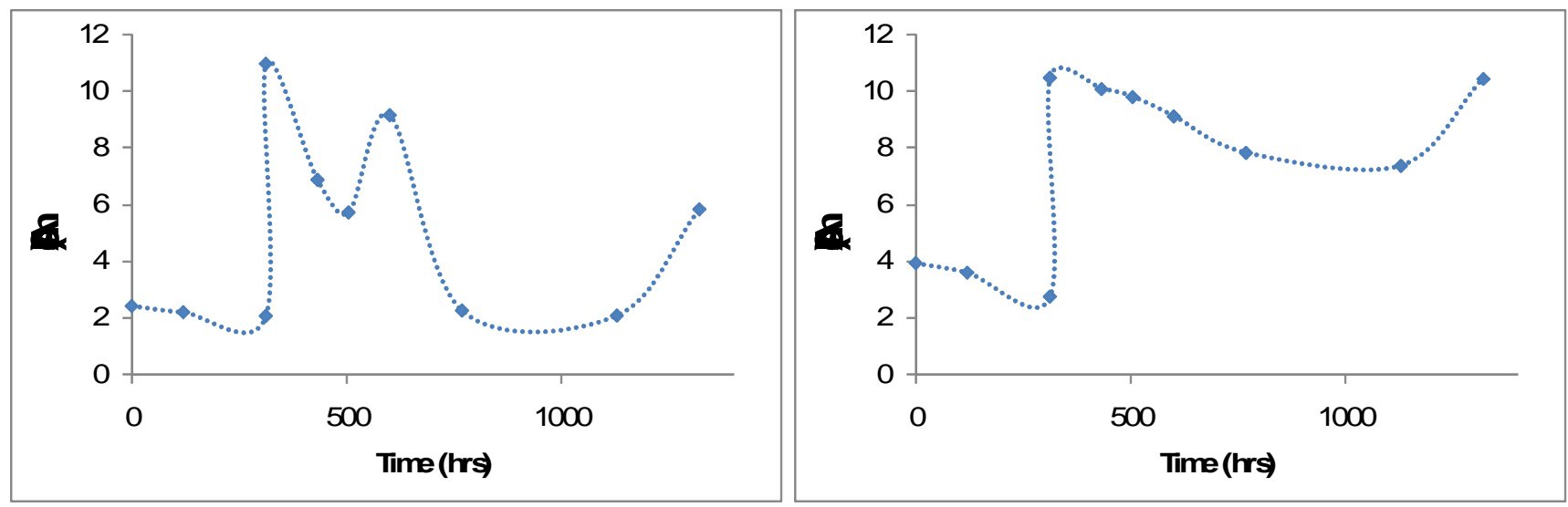

Figure 21. Examples of unreadable data.

\subsection{Future work and recommended guidelines based on this work}

This work revealed a number of issues that need to be further studied:

- The sensitivity of OPVs towards the light spectrum can lead to underestimation of the performance due to lower content of UV in the most indoor light sources compared to real sun in cases where photo-doping is an important element of device performance.

- If the timescale of the dynamic changes in the photovoltaic response for the tested devices are in the same range as the frequency of the measurements, it can result in an inaccurate estimation of the lifetime (such as T80) of a device. 
Other methods for accurate estimation of a device lifetime in such a case are required.

- Handling of flexible devices or mechanical stresses can significantly affect the degradation kinetics.

- A number of temperature/relative humidity combinations have to be defined and employed for stability studies under indoor conditions (both in dark and light) among all the laboratories.

- Light sources with defined spectral distributions have to be used for light soaking test in order to obtain comparable data for device lifetimes.

- A method is required for correct determination of light intensity in outdoor studies and accurate correlation of IV measurements with the measured light intensity, which can significantly improve the accuracy of quantification of the lifetimes in outdoor conditions.

- Load conditions have to be defined for devices stored under light. The approach has to meet the capabilities of all or most of the groups.

\subsection{Conclusions}

Inter-laboratory stability studies of roll-to-roll coated organic solar cell devices were performed. Lifetimes of the devices were within a few hundred hours in average, which allowed for various types of testing across different laboratories. Five categories of stability testing were established based on the ISOS-1\&2 protocols. Twenty four laboratories from ten countries and across four continents carried out 
different tests. Deviations across the laboratories and within the same laboratory for photovoltaic parameter decay were calculated and compared. The advantages and disadvantages of various testing procedures were discussed and a a set of guidelines for future work was suggested. The results can help in establishing standardized procedures for stability testing of OPV devices.

\section{Acknowledgements}

This work was supported by: the Danish Strategic Research Council (DSF 2104-050052 and 2104-07-0022), EUDP (j. nr. 64009-0050), PV-ERA-NET (project acronym POLYSTAR), the Spanish Ministry of Science and Innovation, MICINN for the projects ENE2008-04373 and PIE-200860I134. To the Xarxa de Referència en Materials Avançats per a l'Energia, XaRMAE (Reference Center for Advanced Materials for Energy) of the Catalonia Government. Amanda Florendo, Jaynae Brust, Peter Williamson and David Webb, DSET Laboratories, 45601 N. $47^{\text {th }}$ Avenue, Phoenix, AZ 85087-7042, USA. Tony Hall and Jorge Rivera, South Florida Test Service, 16100 SW $216^{\text {th }}$ Street, Miami, FL 33170 , USA. E.V. and T.A. would like to acknowledge Polystar for partial funding. AE would like to thank Detlef Riesebeck and Kerstin Pollok for technical assistance and the Federal Ministry of Education and Research Germany (Grant Number: 03X3518C) for funding. Financial support by the Austrian Research

Promotion Agency (FFG), the Christian Doppler Research Association (CDG), the Austrian Federal Ministry of Economy, Family and Youth (BMWFJ) and the 
ISOVOLTAIC GmbH is gratefully acknowledged. Part of this work was supported by the PCCL (project IV-1.02) within the framework of the COMET-program of the Austrian Government. MH, TM and KL would like to thank the Bundesministerium fuer Bildung und Forschung in the frameworks of the InnoProfile project (03IP602), the OPEG project (13N9720) and the OPA project (13N 9872). HH gratefully acknowledges funding within the frame of BMBF OPV program. This work has been supported by KIST internal research fund under the contract number of 2E21831. This work has been supported in part by the European Commission as part of the Framework 7 ICT 2009 collaborative project HIFLEX (Grant Agreement number 248678)) and by the Dutch ministry of economic affairs of the Netherlands. MR and MGC thank Craig Barney and David Chaskelmann from Stanford University Environmental Health\&Safety for their support and providing the Stanford weather data. We would like to thank Annette Einsbor Ræbild for technical support.

\section{References}

[1] F. C. Krebs, S. A. Gevorgyan, B. Gholamkhass, S. Holdcroft, C. Schlenker, M. E. Thompson, B. C. Thompson, D. Olson, D. S. Ginley, S. E. Shaheen, H. N. Alshareef, J. W. Murphy, W. J. Youngblood, N. C. Heston, J. R. Reynolds, S. Jia, D. Laird, S. M. Tuladhar, J. G. A. Dane, P. Atienzar, J. Nelson, J. M. Kroon, M. M. 
Wienk, R. A. J. Janssen, K. Tvingstedt, F. Zhang, M. Andersson, O. Inganäs, M. Lira-Cantu, R. de Bettignies, S. Guillerez, T. Aernouts, D. Cheyns, L. Lutsen, B. Zimmermann, U. Würfel, M. Niggemann, H.-F. Schleiermacher, P. Liska, M. Grätzel, P. Lianos, E. A. Katz, W. Lohwasser, B. Jannon, A round robin study of flexible large-area roll-to-roll processed polymer solar cell modules, Sol. Energy Mater. Sol. Cells 93 (2009) 1968-1977.

[2] H. Ossenbrink, K. Krebs, R. V. Steenwinckel, Results of the 1984/1985 international round robin calibration summit working group on technology, growth and employment, IEEE (1985) 943 -944.

[3] J. Metzdorf, T. Wittchen, K. Heidler, K. Dehne, R. Shimokawa, F. Nagamine, H. Ossenbrink, L. Fornarini, C. Goodbody, M. Davies, K. Emery, R. Deblasio, "Objectives and Results of the PEP '87 Round-Robin Calibration of Reference Cells and Modules," Proc. 21 st IEEE Photovoltaic Specialists Conf., Orlando, FL, May 21 -25, 1990, pp. 952-959, IEEE, New York, 1990.

[4] J. Metzdorf, T. Wittchen, K. Heidler, K. Dehne, R. Shimokawa, F. Nagamine, H. Ossenbrink, L. Fornarini, C. Goodbody, M. Davies, K. Emery, R. Deblasio, "The Results of the PEP '87 Round-Robin Calibration of Reference Cells and Modules,- Final Report" PTB technical report PTB-Opt-31, Braunschweig, Germany, November 1990, ISBN 3-89429-067-6.

[5] C. R. Osterwald, S. Anevsky, A. K. Barua, J. Dubard, K. Emery, D. King, J. Metzdorf, F. Nagamine, R. Shimokawa, N. Udayakumar, Y. X. Wang, W. Zaaiman, 
A. Zastrow, J. Zhang, "Results of the PEP '93 Intercomparison of Reference Cell Calibrations and Newer Technology Performance Measurements," Proc. 25th IEEE Photovoltaic Specialists Conf., Washington D.C., May 13-17, 1996, pp. 1263 - 1266, IEEE, New York, 1996.

[6] C. R. Osterwald, Results of 1992 ASTM cell and module measurement intercomparison, IEEE, (1993) 1102-1106.

[7] C. R. Osterwald, S. Anevsky, K. Bücher, A. K. Barua, P. Chaudhuri, J. Dubard, K. Emery, B. Hansen, D. King, J. Metzdorf, F. Nagamine, R. Shimokawa, Y. X. Wang, T. Wittchen, W. Zaaiman, A. Zastrow, J. Zhang, The world photovoltaic scale: An international reference cell calibration program, Prog. Photovolt: res. Appl. 7 (1999) $287-297$.

[8] T. R. Betts, R. Gottschalg, D. G. Infield, W. Kolodenny, M. Prorok, T. Zdanowicz, N. vand der Borg, H. de Moor, G. Friesen, A. Guerin de Montgareuil, W. Herrmann, Round robin comparison of european outdoor measurement systems, 21 st European Photovoltaic Solar Energy Conference, 4-8 September 2006, Dresden Germany, pp. 2447-2451.

[9] W. Herrmann, S. Mau, F. Fabero, T. Betts, N. van der Borg, K. Kiefer, G. Friesen, W. Zaaiman, Advanced intercomparison testing of PV modules in European test laboratories, 22nd European Photovoltaic Solar Energy Conference, 3-7 September 2007, Milan. Italy, pp. 2506-2510. 
[10] M. Jørgensen, K. Norrman, F. C. Krebs, Stability/degradation of polymer solar cells, Solar Energy Mater. Solar Cells 92 (2008) 686-714.

[11] ISOS-1, ISOS-2, http://www.wikispaces.com/opvlifetime

[12] F. C. Krebs, S. A. Gevorgyan, J. Alstrup, A roll-to-roll process to flexible polymer solar cells: model studies, manufacture and operational stability studies, J. Mater. Chem. 19 (2009) $5442-5451$.

[13] F. C. Krebs, Polymer solar cell modules prepared using roll-to-roll methods: Knife-over-edge coating, slot-die coating and screen printing, Sol. Energy Mater. Sol. Cells 93 (2009) $465-475$.

[14] M. R. Lilliedal, A. J. Medford, M. V. Madsen, K. Norrman, F. C. Krebs, The effect of post-processing treatments on inflection points in current-voltage curves of roll-to-roll processed polymer photovoltaics, Solar Energy Mater. Sol. Cells 94 (2010) 2018-2031.

[15] F. C. Krebs, T, Tromholt, M. Jørgensen, Upscaling of polymer solar cell fabrication using full roll-to-roll processing, Nanoscale 2 (2010), 2, 873-886.

[16] F. C. Krebs, J. Fyenbo, M. Jørgensen, Product integration of compact roll-toroll processed polymer solar cell modules: methods and manufacture using flexographic printing, slot-die coating and rotary screen printing, J. Mater. Chem. 20 (2010) 8994-9001.

[17] ISOS-3 consensus on OPV stability testing procedures (this issue). 
[18] J. A. Hauch, P. Schilinsky, S. A. Choulis, S. Rajoelson, C. J. Brabec, The impact of water vapor transmission rate on the lifetime of flexible polymer solar cells, Appl. Phys. Lett. 93 (2008) 103306.

[19] K. Norrman, S.A. Gevorgyan, F.C. Krebs, Water-induced degradation of polymer solar cells studied by $\mathrm{H}_{2}{ }^{18} \mathrm{O}$ labeling, ACS Appl. Mater. Interfaces 1 (2009) 102 112.

[20] K. Norrman, M. V. Madsen, S. A. Gevorgyan, F. C. Krebs, Degradation patterns in water and oxygen of an inverted polymer solar cell, J. Am. Chem. Soc. (2010) Accepted. 